\title{
Consideraciones generales sobre la invalidez en el Derecho Administrativo $^{1}$
}

\author{
Tomás Cano Campos (España) \\ Universidad Complutense de Madrid \\ tcano@der.ucm.es
}

\section{NOTA BIOGRÁFICA}

Tomás Cano Campos es catedrático de Derecho Administrativo de la Universidad Complutense de Madrid. Doctor en Derecho por la Universidad de Bolonia. Sus líneas de investigación se centran en la invalidez de los actos y de las normas, las sanciones administrativas, los contratos públicos y el tráfico, la responsabilidad patrimonial, los transportes y la movilidad.

\section{RESUMEN}

El presente trabajo pretende ofrecer una construcción conceptual y funcional de la invalidez de los actos en el Derecho administrativo que contribuya a salir del enredo conceptual en el que a veces estamos instalados, destaque adecuadamente sus elementos estructurales y ofrezca una explicación plausible de la aparente escisión entre las consecuencias de la invalidez y su proyección en el plano de la realidad. También se ocupa de las relaciones entre tiempo y validez, ensayando la posibilidad de una teoría de la invalidez sobrevenida.

\section{PALABRAS CLAVE}

llegalidad; invalidez; nulidad de pleno derecho; anulabilidad; ineficacia; anulación; invalidez sobrevenida.

\begin{abstract}
The present work intends to offer a conceptual and functional construction of the invalidity of the acts in the Administrative Law that contributes to get out of the conceptual entanglement in which we are sometimes installed, adequately highlight its structural elements and offer a plausible explanation of the apparent split between the consequences of invalidity and its projection on the plane of reality. It also focus its attention in the relationships between time and validity, rehearsing the possibility of a theory of consequential invalidity of administrative acts.
\end{abstract}

\section{KEYWORDS}

Illegality; invalidity; legal nullity; annulability; ineffectiveness; annulment; consequential invalidity.

\section{SUMARIO}

1. INTRODUCCIÓN. 2. LAS DIVERSAS CARAS DEL FENÓMENO: EL CONCEPTO DE INVALIDEZ. 3. LA DISTINCIÓN ENTRE NULIDAD Y ANULABILIDAD. 4. LAS CONSECUENCIAS DE LA INVALIDEZ Y EL MOMENTO EN QUE OPERAN. 5. LOS MEDIOS DE REACCIÓN CONTRA LA INVALIDEZ. 6. LOS PRONUNCIAMIENTOS DE INVALIDEZ: ¿CARÁCTER CONSTITUTIVO O DECLARATIVO? 7. LA SITUACIÓN CREADA POR LOS ACTOS INVÁLIDOS Y SU PROTECCIÓN. 8. TIEMPO Y VALIDEZ: LA INVALIDEZ SOBREVENIDA. BIBLIOGRAFIA.

\footnotetext{
1 Proyecto de investigación del Ministerio de Economía y Competitividad (MINECO/FEDER) DER2015-65524-R y Grupo de Investigación 931089 de la Universidad Complutense de Madrid.
} 


\section{INTRODUCCIÓN}

La invalidez constituye, seguramente, unos de los conceptos más confusos y escurridizos de la teoría del Derecho en general y de la dogmática jurídica en particular. La importancia del tema ha llevado a los juristas a ocuparse de él de forma recurrente, pero los resultados obtenidos no han logrado ofrecer una construcción acabada que evite las constantes críticas y revisiones de que el tema es objeto por parte de cada autor que se aproxima a él con cierta profundidad. Ello es especialmente claro en el ámbito del Derecho Administrativo, donde, a pesar del avance en los últimos años, el concepto de invalidez no siempre es utilizado con el mismo significado y donde todavía no se ha elaborado una teoría que integre a todos los elementos del fenómeno, aclare debidamente sus efectos o consecuencias y explique su funcionamiento real en el sistema.

Soy consciente de que aportar algo coherente, y no digamos ya interesante, sobre el régimen de la invalidez en el Derecho Administrativo en unas pocas líneas no es una tarea fácil. Pero lo intentaré. En este trabajo me voy a centrar especialmente en la invalidez de los actos o resoluciones administrativas, ya que otros estudios de este mismo número de la Revista se ocupan de las demás formas de la actividad de la Administración. En particular voy a abordar algunas de las cuestiones generales que considero más discutidas y discutibles, y que tampoco serán tratadas en el resto de trabajos que componen este número. Las voy a agrupar en torno a tres grandes bloques o apartados: un primer bloque de tipo conceptual, otro relativo a las consecuencias de la invalidez y un último apartado sobre el problema de las relaciones entre tiempo y validez.

Con ello, y sobre la base de otros trabajos previos que ya he publicado sobre el tema, tan sólo pretendo ofrecer una modesta construcción conceptual y funcional de la invalidez que contribuya a salir del enredo conceptual en el que a veces estamos instalados, destaque adecuadamente sus elementos estructurales y ofrezca una explicación plausible de la aparente escisión entre las consecuencias de la invalidez y su proyección en el plano de la realidad.

\section{LAS DIVERSAS CARAS DEL FENÓMENO: EL CONCEPTO DE INVALIDEZ}

En ocasiones decimos que un acto es válido o inválido, para significar que de ello se derivan determinados efectos o consecuencias jurídicas (por ejemplo, en el caso de la invalidez que el acto es ineficaz), mientras que otras la validez o invalidez apunta a las condiciones o antecedentes de lo que calificamos como tal, y entonces decimos, por ejemplo, que un acto es válido porque ha sido dictado cumpliendo los requisitos de la Ley 39/2015, de 1 de octubre, de Procedimiento Administrativo Común (en adelante, LPAC). Ello supone que, a propósito de la validez e invalidez, podemos referirnos tanto a sus condiciones o antecedentes (o a su negación: los vicios de validez) como a sus consecuencias: a cuáles son los efectos de que cierto resultado institucional (acto, contrato, sentencia, ley) sea válido o inválido².

Por eso, una teoría de la invalidez consiste, básicamente, en una teoría de los requisitos de la validez y en una teoría de los efectos o consecuencias de la invalidez. Mientras que la primera trata de responder a la pregunta de cuándo es válido o inválido un acto administrativo, la segunda responde a cuales son los efectos o consecuencias que se derivan de la declaración de invalidez ${ }^{3}$. Dicha teoría se ha de completar con el régimen para declarar la invalidez y al carácter y efectos de los pronunciamientos autoritativos que la declaran.

La invalidez se puede definir como la condición del acto contrario al ordenamiento cuyos efectos carecen por ello de tutela o protección. Como veremos, cuando un acto administrativo ha sido dictado incumpliendo (algunas de) las normas que regulan su producción, el ordenamiento jurídico no protege sus efectos, mientras que tutela el interés a su remoción poniendo a disposición de los interesados un determinado régimen de invalidación o anulación.

La invalidez, como todos sabemos, es la consecuencia de un vicio o defecto (formal o material). Un vicio, por su parte, es el efecto de la violación de una norma sobre la producción del acto (competencia,

2 M. ATIENZA y J. RUIZ MANERO (2003: 720). Apuntan la misma idea J. L. VILLAR PALASÍ y J. L. VILLAR EZCURRA (1999: 154-155) cuando afirman que los grados de invalidez - nulidad y anulabilidad- son entendidos "como causa y como efectos simultáneamente».

${ }^{3}$ M. ATIENZA y J. RUIZ MANERO (2003: 731); H. MAURER (2011: 265). La idea fue apuntada también por J. A. SANTAMARÍA PASTOR (1975: 49, 61-69), quien denunció que la «anarquía terminológica» se debe a la confusión de esos dos planos y el procesal que a continuación cito en el texto y que para él es el esencial. 
procedimiento, forma) y la determinación de su contenido (posibilidad, determinación, adecuación al ordenamiento). Por tanto, la invalidez resulta de la contrariedad a Derecho, aunque no toda contrariedad a Derecho determina la invalidez del acto, ya que hay vicios o irregularidades no invalidantes. Se puede hablar también, como hacen algunos autores, de ilegalidades no invalidantes y, por tanto, de actos ilegales pero válidos.

Pero, a mi modo de ver, la escisión entre ilegalidad (o irregularidad) e invalidez sólo se da en este supuesto de las irregularidades no invalidantes, por lo que sólo en estos casos (que no son pocos) puede afirmarse con propiedad que un acto es válido a pesar de vulnerar el ordenamiento jurídico. Sin embargo, en mi opinión, no se pueden considerar válidos los actos ni cuando presentan un vicio invalidante pero ya no se puede declarar su invalidez (por ejemplo, porque el acto no se haya recurrido en plazo o ya no se pueda revisar de oficio) ni tampoco cuando el ordenamiento proteja y mantenga sus efectos a pesar de que incurre en vicios de nulidad o de anulabilidad. En estos casos, el acto no deviene por ello conforme a Derecho.

En el primer caso, el paso del tiempo no hace válido lo inválido o regular lo irregular, como tampoco cabe pensar que el tiempo prive al acreedor de su condición de tal o convierta el asesinato en una acción lícita; y, sin embargo, el crédito y la acción para perseguir el delito están sujetos a la disciplina del tiempo, es decir, a los plazos de prescripción ${ }^{4}$. Frente a lo que a veces se afirma, el transcurso del tiempo no sana o convalida la irregularidad, sino que hace que ésta deje de ser relevante para el Derecho. La irregularidad subsistirá pero, por razones de seguridad jurídica, ya será tarde para discutir si existe o no y la situación creada por el acto ya no podrá removerse.

En el segundo supuesto, como se verá, el que se mantengan los efectos de un acto declarado inválido es la consecuencia que el Derecho anuda a otros principios del sistema. Pero tales principios no se erigen en canon de validez del acto, por lo que éste no puede considerarse conforme a Derecho. Si consideráramos que en estos casos el acto es válido, no se explicaría por qué en ocasiones los efectos que se mantienen no son los mismos que los que se derivan del propio acto (por ejemplo, en las expropiaciones declaradas nulas, una indemnización superior al justiprecio por la pérdida de la propiedad).

Además, con esa forma de entender la validez no se formula juicio de reproche alguno a la Administración cuando vulnera la legalidad a la que está sometida. Y el concepto de validez se esfuma o difumina en el de eficacia. Por el contrario, si concluimos, como creo que debe hacerse, que en tales casos el acto es inválido y el órgano de control así lo debe declarar, se estará destacando que la Administración no debió dictar nunca un acto de esa forma o con ese contenido y que por ello no podría dictarlo ahora. La declaración de invalidez cumple en tales casos un papel análogo al de las sanciones, pues implica, como éstas, un juicio de reproche que consiste en destacar que no se ha respetado la legalidad al haberse usado de forma antijurídica la norma que confiere la potestad ${ }^{5}$.

\section{LA DISTINCIÓN ENTRE NULIDAD Y ANULABILIDAD}

Una segunda cuestión conceptual a la que quiero referirme es la relativa a la distinción entre la nulidad y la anulabilidad. Nuestro Derecho no regula de forma general y de manera abstracta la invalidez de los actos administrativos, sino que establece grados, tipos, clases, modalidades, regímenes típicos (son algunas de las diversas expresiones que suelen utilizarse) de invalidez, en concreto, las referidas categorías de la nulidad de pleno derecho y la anulabilidad ${ }^{6}$.

Conviene destacar que no se trata de categorías lógicas o abstractas que puedan descubrirse o elaborarse con razonamientos de ese tipo, sino que constituyen la regulación que el legislador ha estatuido para tratar diferentes casos o grupos de casos de actos que infringen el ordenamiento jurídico ${ }^{7}$. La nulidad y la

4 M. PASQUAU LIAÑO (1997: 286) y (2007: 233).

5 Vid. M. ATIENZA RODRÍGUEZ y J. RUIZ MANERO, J. (2003: 732); J. A. PÉREZ LLEDÓ (2015: 34, por nota). Eso no quiere decir, lógicamente, que la invalidez sea una sanción entendida como castigo o retribución, pues cuando algunos autores afirman que la nulidad es una sanción están utilizando este término en un sentido amplio (y no técnico) como equivalente a consecuencia jurídica o reacción que el ordenamiento prevé por la realización de algo contrario a Derecho.

6 La Ley 30/1992, de 26 de noviembre, de Régimen Jurídico de las Administraciones Públicas y del Procedimiento Administrativo Común (en adelante, LRJPAC) sustituyó la expresión «Invalidez», que era la rúbrica que englobaba a los arts. 47 a 55 de la LPA de 1958, por los términos «Nulidad y anulabilidad», que encabezaban la regulación de sus arts. 62 a 67 , como ahora encabezan la de los arts. 47 a 52 de la nueva LPAC.

7 Vid. J. L. BERDEJO LACRUZ, A. LUNA SERRANO, J. DELGADO ECHEVERRÍA, F. RIVERO HERNÁNDEZ, (1987: 350); J. DELGADO ECHEVERRÍA, M. A. PARRA LUCÁN (2003: 18). 
anulabilidad son, realmente, conceptos que condensan el tratamiento o la disciplina normativa aplicable a los actos que presentan determinados vicios; más exactamente, regímenes típicos de la invalidez de los actos administrativos que el ordenamiento configura en función de los intereses en juego y de la protección que a cada uno de ellos decide dispensar. Constituyen, por tanto, regulaciones de Derecho positivo y, por ello, es de éste del que hay que partir para extraer las diferencias que median entre una y otra categoría ${ }^{8}$.

Por eso, en mi opinión, hay que huir aquí de todo esencialismo conceptual y de los dogmas, a veces mal entendidos, de la teoría clásica. Nuestro Derecho Administrativo se aleja del planteamiento tradicional del Derecho Civil y de la oposición frontal entre la nulidad y la anulabilidad, quizá por la amplitud de la nulidad de pleno derecho, que no sólo se reserva a los actos que presentan los vicios más graves y evidentes.

Para apreciar las diferencias reales entre una y otra categoría hay que partir, en efecto, de los datos que ofrece el ordenamiento jurídico. Así, por ejemplo, no es cierto que los actos nulos de pleno derecho sean ineficaces desde el principio. Lo desmienten, entre otros, el art. 39.1 LPAC, que predica la presunción de validez de todos los actos y dispone su eficacia inmediata desde que se dictan, o los arts. 108 y 117.2 de mismo texto legal, que también parten de la eficacia de los actos nulos al prever la posibilidad de suspender su ejecución.

Nuestro Derecho positivo, como se verá, también desmiente otras supuestas diferencias como el carácter ex tunc de la nulidad y ex nunc de la anulabilidad, o la naturaleza declarativa de los pronunciamientos de aquélla y la naturaleza constitutiva de los de ésta. Las diferencias entre la nulidad de pleno derecho y la anulabilidad se circunscriben, esencialmente, a la convalidación, la revisión de oficio, la acción de nulidad y el régimen de suspensión. Veámoslo muy sintéticamente.

- Convalidación por subsanación. El art. 52 de la LPAC sólo habilita a la Administración para convalidar los actos anulables mediante su subsanación. Algunos autores han sostenido que también algunos vicios de nulidad de pleno derecho se pueden subsanar, mientras que otros de anulabilidad no serían subsanables. Ello es cierto, pero no debe confundirse la posibilidad material de que un determinado vicio (de nulidad o de anulabilidad) se pueda subsanar, con la posibilidad jurídica de la subsanación, esto es, con la autorización por el Derecho de que algo que realmente puede ser subsanado lo sea jurídicamente. Hay actos nulos de pleno derecho, en efecto, que podrían ser realmente subsanados porque el concreto vicio en que incurren es susceptible de ello desde un punto de vista lógico o material, pero el legislador no está vinculado por esa circunstancia y puede no habilitar a la Administración para que proceda a su convalidación. Esto es -entiendo- lo que antes hacía el art. 67 de la LRJPAC y ahora hace el art. 52 de la nueva LPAC al apoderar a la Administración para que sólo convalide los actos que incurren en vicios de anulabilidad. Puede ser criticable, y a mi me lo parece, pero es así.

- Revisión de oficio. Mientras que el art. 106 de la LPAC establece que las Administraciones públicas, en cualquier momento, declararán de oficio la invalidez de los actos nulos de pleno derecho, el art. 107 de la misma disposición legal no habilita a la Administración con esa potestad, de modo que los actos anulables (favorables) no pueden ser revisados de oficio por la Administración: ésta tiene que acudir a la vía de la declaración de lesividad de tales actos y a su posterior impugnación ante la jurisdicción contencioso-administrativa ${ }^{9}$. Sin embargo, el régimen de suspensión en la revisión de oficio de los actos nulos y en la revocación de los actos anulables es el mismo (art. 108), al igual que los limites a una y otra (art. 110).

- Acción de nulidad. El art. 106 de la LPAC reconoce a cualquier interesado el derecho subjetivo a exigir a la Administración, también en cualquier momento, la declaración de nulidad de los actos administrativos que hayan incurrido en un vicio de nulidad de pleno derecho, y ello tanto si el acto es favorable como si es de gravamen ${ }^{10}$. Se trata de una acción que el ordenamiento sólo reconoce

\footnotetext{
8 Como señala L. DIEZ-PICAZO, (2007: 564), el legislador no se encuentra vinculado por ninguna de estas posibles categorías dogmáticas y puede dotar a cada una del contenido que estime más conveniente. Y es un error pensar lo contrario.

9 Este diferente tratamiento ha sido criticado por algunos autores. Vid. R. BOCANEGRA SIERRA (2012: 216); J. GARCÍA LUENGO (2010: 25-26).

10 Vid. M. REBOLLO PUIG y E. CARBONELL PORRAS (2018: 186) que lo argumentan así: tiene sentido admitir esta vía tanto para los actos favorables como para los de gravamen, pues si el acto es favorable para un particular puede que otro esté interesado en su nulidad, y, si es desfavorable, el mismo destinatario del acto puede estar interesado en instar esta revisión ya que no tiene otro cauce para ello, a diferencia de lo que ocurre con la Administración que, para los actos de gravamen, ya tiene la vía, más sencilla, del art. 109.1 de la LPAC.
} 
para los actos nulos de pleno derecho, pero para ejercerla es preciso estar legitimado («a solicitud de interesado», dice el art. 106.1 LPAC), pues la acción de nulidad no es una acción popular. Si el acto es anulable, el particular, lo único que puede hacer, es interponer los recursos administrativos o jurisdiccionales pertinentes. En vía de recurso administrativo también se establece una diferencia en relación a los sujetos legitimados para invocar los vicios de nulidad y de anulabilidad. Así, el art. 115.3 de la LPAC, al regular la interposición de los recursos administrativos, dispone que: «Los vicios y defectos que hagan anulable un acto no podrán ser alegados por quienes los hubieren causado». Esta regla sólo afecta a los particulares, pero no a la Administración (que lógicamente no es recurrente), y únicamente se predica, como puede verse, de los actos anulables, aunque la jurisprudencia la ha extendido también a las impugnaciones torticeras de actos nulos por parte de los particulares ${ }^{11}$. Pero, como se ha resaltado, fuera de estos supuestos, las reglas de legitimación son las mismas para la nulidad y para la anulabilidad ${ }^{12}$.

- Régimen de la suspensión en los recursos administrativos. También debe destacarse la diferencia que establece el art. 117.2.a) LPAC respecto de la suspensión de la ejecución de los actos nulos de pleno derecho y los actos anulables. De ese precepto se deduce que, en principio, es más fácil conseguir la suspensión en caso de nulidad que en los supuestos de anulabilidad, pues uno de los criterios que el órgano administrativo ha de tener en cuenta para acordar la suspensión de la ejecución de un acto impugnado en vía de recurso es que dicha impugnación se fundamente en que el acto incurre en nulidad de pleno derecho. Se trata de obstaculizar la materialización de los efectos de los actos nulos de pleno derecho, dada la gravedad de los vicios en que los mismos incurren. En la práctica, sin embargo, la invocación de la nulidad como causa de la suspensión no parece que sea muy atendida ${ }^{13}$.

Además de estas diferencias, que son de estricto Derecho positivo, hay otras que se deducirían de una interpretación institucional del concepto de nulidad de pleno derecho y que han sido sostenidas por parte de la doctrina y de la jurisprudencia. Pero respecto de algunas de ellas no reina acuerdo y otras carecen de todo fundamento.

Una diferencia, según algunos autores, sería la posibilidad de utilizar la vía interdictal en los casos de ejecución de los actos que incurren en nulidad de pleno derecho, por ser ello constitutivo de una vía de hecho, lo que no ocurre si se trata de ejecutar actos anulables ${ }^{14}$. Algunos autores y cierta jurisprudencia también han sostenido que debe haber una prioridad del enjuiciamiento de las causas de nulidad de pleno Derecho, de modo que sólo tras apreciar que éstas no concurren procede analizar los requisitos de admisibilidad del recurso. Pero esto no se infiere del concepto, no lo establece el Derecho positivo [arts. 51.1, 58, 59 y 69 de la Ley 29/1998, de 13 de julio, reguladora de la Jurisdicción Contencioso-administrativa (en adelante, LJCA)] y hoy parece superado tanto por la doctrina como por la jurisprudencia, de modo que la necesidad de declarar judicialmente la nulidad requiere de un proceso en regla y con todas las garantías, incluido el esquema admisibilidad/fondo ${ }^{15}$. No obstante, algunos excluyen de dicho esquema la inadmisiblidad del recurso contra los actos confirmatorios prevista en el art. 28 LJCA, que, a pesar de que el precepto no distingue, sólo se aplicaría a los actos anulables ${ }^{16}$. También se han destacado otras diferencias entre la

11 S. MUÑOZ MACHADO (2018: 190).

12 M. BELADIEZ ROJO (1994b: 169); G. DOMÉNECH PASCUAL (2002: 98); V. S. BACA ONETO (2006: 86); M. REBOLLO PUIG (2009: 107).

13 J. JORDANO FRAGA (1996: 183).

14 J. GARCÍA LUENGO (2002: 252-253). En contra, F. LÓPEZ MENUDO (1998: 317), que sólo admite los interdictos en los supuestos de las letras b) y e) del art. 62.1 LRJPAC (hoy art. 47 de la LPAC), por ser los únicos constitutivos de vía de hecho. En el mismo sentido, M. REBOLLO PUIG (2009: 34), quien precisa que se está hablando de actos nulos de pleno derecho no declarados como tales por los órganos competentes para ello, pues si se ejecuta un acto ya anulado sí estaríamos ante una vía de hecho.

${ }_{15}$ Afirma la prioridad del examen de las causas de nulidad, entre otros, P. MENÉNDEZ GARCÍA (2001: 22). En contra, con argumentos convincentes, A. HUERGO LORA (2000: 236); M. REBOLLO PUIG (2009: 21). Sobre las contradicciones jurisprudenciales en la prioridad del enjuiciamiento de las causas de nulidad, J. GARCÍA LUENGO (2002: 246). Pero la jurisprudencia más reciente es clara: «la posible concurrencia de una causa de nulidad de pleno derecho no es motivo para que deje de apreciarse la extemporaneidad del recurso, pues la interposición del recurso contencioso-administrativo debe atenerse al plazo legalmente previsto [...] porque lo que no está sometido a plazo es el ejercicio de la acción de nulidad en vía administrativa» (STS de 10 de abril de 2012, recurso núm. $6401 / 2009$, que cita otras muchas anteriores).

16 J. L. VILLAR PALASÍ y J. L. VILLAR EZCURRA (1998: 277, 284); J. GONZÁLEZ PÉREZ (2011:398); A. HUERGO LORA (1999: 554-555); J. GARCÍA LUENGO (2002: 290); S. MUÑOZ MACHADO (2018: 39). Con matices M. REBOLLO PUIG (2009: 24-25). En contra, J. A. SANTAMARÍA PASTOR, B. LOZANO CUTANDA, J. P. QUINTANAR CARRETERO, R. CASTILLO BADAL (2014: 525-526). 
nulidad y la anulabilidad como, por ejemplo, la posibilidad de invocar la nulidad de pleno derecho de un acto para conseguir la nulidad de otro, o la posibilidad de alegarla como excepción procesal en la jurisdicción contencioso-administrativa o en otra jurisdicción distinta, lo que no sería posible en los supuestos de anulabilidad y concuerda perfectamente con el carácter imprescriptible de la nulidad que consagra el actual art. 106 LPAC $^{17}$

Sin embargo, no me parece acertada la tesis que hace distingos a efectos de la interrupción de la prescripción. Según la jurisprudencia mayoritaria los actos anulables de aplicación del tributo interrumpen la prescripción mientras que los que se declaren nulos de pleno derecho no, «pues en ellos el vicio invalidante y "ab origine" que padecen hace que se tengan por inexistentes desde que se dictaron y no pudieron surtir efectos, por lo que tampoco despliegan sus efectos para interrumpir la prescripción» [SSTS de 28 de junio de 2010, recurso de casación núm. 96/2006), de 27 de marzo de 2012 (recurso de casación núm. 5827/2009) y de 19 de noviembre de 2012 (recurso de casación en interés de ley núm. 1215/2011]. Pero esto es criticable porque, como señala el voto particular a tales sentencias, en ningún precepto de la LRJPAC (o ahora en la LPAC) ni de la Ley General Tributaria se establece que un acto viciado de nulidad de pleno derecho no interrumpa la prescripción mientras que sí lo haga un acto en el que concurre un vicio de anulabilidad, de modo que, a efectos de la interrupción de la prescripción, resulta irrelevante el grado de invalidez del acto. El legislador debería regular expresamente los efectos que produce la invalidez sobre la prescripción, porque, aunque hay argumentos para sostener que en tales casos la Administración, aun con defectos, está persiguiendo la infracción cometida y, por tanto, no hay dejación o abandono de sus poderes punitivos que justifiquen la prescripción de la infracción, también se puede argumentar que, como la prescripción en el ámbito punitivo no es la consecuencia del abandono presumible de un derecho por su no ejercicio, sino una institución al servicio de la seguridad jurídica y de la función de las sanciones, ni los actos nulos ni los anulables deberían interrumpir la prescripción ya que no deberían haber producido efecto alguno.

Frente a la tesis que acentúa las diferencias entre la nulidad y la anulabilidad o la opinión de quienes diluyen casi por completo la distinción, quizá debería ensayarse un sistema más dúctil y flexible que diversifique el régimen jurídico de la invalidez en función del tipo de irregularidad y no someta todos los supuestos al rígido esquema binario o dual que nos acompaña desde hace tiempo ${ }^{18}$. La propia doctrina civilista ha comenzado ya a cuestionar la concepción dual o bipartita y ha propugnado la formulación de una nulidad de pleno derecho plural y flexible, cuyo régimen jurídico pueda modularse y plegarse al interés protegido por la concreta norma de nulidad; una nulidad que pueda ser relativa, o prescribible, o convalidable o no apreciable de oficio, que permita así encontrar respuestas más adecuadas a cada tipo de vicio o irregularidad ${ }^{19}$. Algunos autores han insistido en esta idea y, por ejemplo, han sostenido la necesidad de relativizar $\mathrm{y}$, sobre todo, diversificar el actual régimen jurídico de algunos supuestos de nulidad de pleno derecho de los actos administrativos y de la propia anulabilidad ${ }^{20}$. Se evitaría así la aplicación en bloque de la disciplina de una u otra categoría y el régimen jurídico de la invalidez se adaptaría al interés protegido por la norma en cada caso vulnerada, pues no todos los requisitos de validez tienen (o deben tener) el mismo valor. Sin descartar, incluso, la posibilidad de prever de forma expresa la ineficacia inicial de los actos que incurran en las irregularidades más groseras, graves y evidentes, como ocurre en otros países de nuestro entorno.

También los planes urbanísticos están demandando con urgencia una teoría de la invalidez más acorde con su verdadera y heterogénea naturaleza jurídica y con las necesidades del urbanismo actual ${ }^{21}$. Y lo mismo cabe decir de los reglamentos, que ven como cualquier irregularidad formal o material en la que incurren se somete sin matiz al severo régimen de la nulidad de pleno derecho, lo que también debe ser corregido

17 M. REBOLLO PUIG (2009: 23 ss.). Sobre la posibilidad de oponer la nulidad por vía de excepción, vid. ya T. R. FERNÁNDEZ RODRÍGUEZ (1969: 67) y (1979: 24).

${ }_{18}$ Sobre la construcción de tales categorías y su contraposición, casi siempre sobre la base de una interpretación errónea y deformada de los textos romanos y una sedimentación de equívocos a lo largo de la historia, vid. el magistral análisis de J. A. SANTAMARÍA PASTOR (1975: 73-152). Vid. también M. PASQUAU LIAÑO (1997: 43-59).

19 Vid. M. PASQUAU LIAÑO (1997: 33) quien se pregunta por qué hacer de la distinción entre nulidad y anulabilidad la única clasificación de la teoría de las nulidades y de qué razones se deriva que todos los supuestos de nulidad de pleno derecho se sometan en bloque a un mismo régimen jurídico y todos los supuestos de anulabilidad hayan de sujetarse al régimen opuesto.

20 M. REBOLLO PUIG (2009: 16-18, 38-39). Vid. también S. MUÑOZ MACHADO (2018: 191) que propone o reducir los supuestos de nulidad o modularlos para reconocer dentro de ellos algunos más debilitados que se asemejen en cuanto a sus consecuencias a la anulabilidad.

${ }^{21}$ Vid. las certeras reflexiones de J. M. ${ }^{a}$ BAÑO LEÓN (2017) y el magnífico trabajo de M. A. GONZÁLEZ SANFIEL (2017: 411 y ss.). 
cuanto antes, pues no parece de recibo que el régimen de los reglamentos ilegales sea incluso más estricto y riguroso que el de las propias leyes inconstitucionales ${ }^{22}$.

\section{LAS CONSECUENCIAS DE LA INVALIDEZ Y EL MOMENTO EN QUE OPERAN}

Paso ahora a las consecuencias de la invalidez. Tales consecuencias son las mismas en los supuestos de nulidad y en los de anulabilidad. Y ello tanto desde el punto de vista material (qué efectos o consecuencias tiene la declaración de invalidez) como temporal (desde qué momento se producen).

Nuestro ordenamiento jurídico no regula de forma expresa los efectos o consecuencias de la declaración de invalidez. No lo hace la LPAC ni tampoco la LJCA, cuyo art. 71.1 se limita a decir que cuando la sentencia estimase el recurso contencioso-administrativo «declarará no ser conforme a Derecho y, en su caso, anulará total o parcialmente la disposición o acto recurrido».

Creo que debe partirse de esta idea: el Derecho sólo otorga tutela o protección a los actos que respetan las normas que establecen su forma de producción y determinan su contenido. Si el acto no respeta tales normas, no debe producir efectos, pues toda la actuación administrativa debe realizarse «con sometimiento pleno a la Ley y al Derecho», según dispone el art. 103.1 de la CE. Pero, por razones institucionales ligadas al interés general al que responde la actuación de la Administración y a la propia función de estabilización y clarificación del Derecho que cumple el acto administrativo, el ordenamiento obliga a presumir su validez, de modo que el acto produce efectos de forma inmediata y surge el deber de actuar sin entrar a analizar si es o no conforme a Derecho hasta que se declare su invalide $z^{23}$. Hasta que esto no tenga lugar, el acto y sus efectos gozan del respaldo del Derecho por muchos vicios o irregularidades que presente y por muy graves que estas sean. Hay así una escisión entre validez y eficacia que da lugar a que se produzcan efectos jurídicos no conformes a Derecho ${ }^{24}$.

Pero cuando un órgano competente para ello declara que el acto es inválido, la situación jurídica creada pierde ese amparo o protección y la legalidad debe ser restablecida o restaurada. El Derecho no tutela los efectos de los actos inválidos. Por eso, en rigor, de la invalidez no se deriva la ineficacia de los actos (pues el acto se presume válido y produce efectos desde que se dicta hasta que se anula), sino el desamparo o desprotección de las situaciones jurídicas creadas por el acto inválido ${ }^{25}$. Su fundamento reside en el principio de legalidad de la Administración que exige el retorno a la situación conforme a Derecho. Se trata de la tutela primaria que ofrece el ordenamiento jurídico y que exige el cese de la situación contraria al ordenamiento, impidiendo que el acto inválido siga produciendo efectos y prescribiendo la remoción de la situación que haya creado como consecuencia de haberse producido al margen de sus mandatos. Si el restablecimiento no es posible procederá el resarcimiento (tutela resarcitoria o secundaria) siempre que concurran los requisitos de la responsabilidad patrimonial. En rigor, si tales requisitos concurren, también cabe esta tutela secundaria junto al restablecimiento de la legalidad, pues la tutela resarcitoria constituye un sistema autónomo de protección ${ }^{26}$.

22 Vid., por todos, G. DOMÉNCH PASCUAL (2002) y el reciente trabajo de F. LÓPEZ RAMÓN (2018: 13 y ss.).

${ }^{23}$ Sobre la presunción de validez, M. REBOLLO PUIG (2005: 587 y ss.); G. DOMÉNECH PASCUAL (2010: 1031 y ss.); T. CANO CAMPOS (2017: 519 y ss.).

${ }^{24}$ La eficacia y la ineficacia deben ser consideradas, en mi opinión, como categorías estrictamente jurídicas. Ambas pertenecen a un mundo institucional (convencional) como es el Derecho, no al mundo físico. La eficacia jurídica del acto no es la efectividad o los efectos de hecho que el acto produce en la realidad, sino los efectos de Derecho, el cambio jurídico que produce en función de su contenido: la calificación normativa de un comportamiento como obligatorio, permitido o prohibido, la atribución, el reconocimiento o negación de una calificación institucional a una clase de personas (por ejemplo a los afectados por una sequía o un terremoto), objetos (por ejemplo como bienes muebles) o estado de cosas (por ejemplo la declaración de zona catastrófica), etc. Por ello, la eficacia jurídica se produce con independencia de la subsiguiente comisión u omisión de otros actos que sean actuaciones de dichos efectos, los cuales no siempre son precisos o necesarios. La eficacia de una orden de demolición, es la obligación de demoler (no la efectiva destrucción del edificio); la de una multa, la obligación de pagarla (no la efectiva realización del pago); la de una licencia de edificación, el derecho a edificar (no la construcción del edificio). Si la eficacia jurídica se moviera en el terreno de los hechos, no cabría hablar, por ejemplo, de una eficacia retroactiva de los actos administrativos como hace el art. 39.3 LPAC, pues lo que ocurre en el terreno de la realidad no puede retrotraerse en el tiempo (el pasado no es modificable materialmente). En este sentido, por ejemplo, A. NIETO GARCÍA (1994: 20); R. BOCANEGRA SIERRA (2012: 126); J. GARCÍA LUENGO, J. (2002: 249). En la teoría del Derecho, entre otros, R. GUASTINI (1999: 321); L. PRIETO SANCHÍS (2005: 83-85); L. FERRAJOLI (2011: 251, 268). Consideran, por el contrario, que la ineficacia es un dato empírico J. A. SANTAMARÍA PASTOR $(1975: 159-161,175)$ y, de forma recurrente, V. S. BACA ONETO $(2006: 44-45,55,77,79)$.

25 T. CANO CAMPOS (2004: 197 y ss.) y (2017: 77 y ss.); S. DÍEZ SASTRE (2017: 281).

26 Vid. L. MEDINA ALCOZ (2005: 307); S. DÍEZ SASTRE (2012: 79). En la jurisprudencia, vid., por ejemplo, la STS de 15 de noviembre de 2012 (recurso de casación núm. 435/2012). 
En concreto, y como consecuencia de la referida privación de fuerza jurídica del acto en que se traduce su declaración de invalidez, si sus efectos jurídicos todavía no se han materializado (no se ha pagado la multa, no se ha percibido la subvención, no se ha construido el edificio), ya no será exigible su cumplimiento ni posible su ejecución, por lo que no se debe proteger ninguna acción encaminada a ello. Si los efectos jurídicos se han materializado, procederá el restablecimiento o restitución al estado anterior a la comisión de la irregularidad determinante de la invalidez del acto (devolución de la cuantía de la multa pagada o reintegro de la subvención indebidamente percibida, demolición del edificio construido vulnerando materialmente las normas). Si el acto denegó algo a lo que se tenía derecho (una licencia, la adjudicación de un contrato o una subvención), la Administración deberá anular el acto y reconocer ese derecho si es ella la que declara la invalidez y, si es la Jurisdicción, además de anular la denegación, deberá condenar a la Administración a que dicte el acto, salvo que en el proceso no sea posible decidir si el demandante tiene o no tal derecho, en cuyo caso lo procedente es anular el acto denegatorio y condenar a la Administración a decidir de nuevo sobre la pretensión del particular de conformidad a Derecho ${ }^{27}$.

En el caso de los vicios de forma invalidantes (invalidez formal), el restablecimiento de la legalidad puede tener lugar con la subsanación, restituyendo, por tanto, el derecho a un procedimiento ajustado a Derecho ${ }^{28}$. Así, al resolverse un recurso administrativo, el órgano competente podrá anular el acto y acordar la convalidación de actuaciones o bien ordenar la retroacción del expediente al momento en que se cometió el vicio para que se proceda a su subsanación (art. 119.2 LPAC). Pero en el proceso contencioso-administrativo se ha criticado la retroacción de actuaciones respecto de los actos de gravamen, en particular en el caso de las sanciones ${ }^{29}$.

Algunos consideran que mientras que en los supuestos de nulidad de pleno derecho estas consecuencias operan ex tunc en los de anulabilidad se producen ex nunc ${ }^{30}$. Pero esto carece de todo fundamento, ni siquiera está presente en la teoría clásica del Derecho Civil y deriva de una utilización incorrecta del argumento a contrario, pues procede del error de considerar que la anulabilidad es el reverso o el envés de la nulidad. En esta cuestión, como en tantas otras relacionadas con la invalidez, hay mucho apriorismo dogmático generalmente aceptado.

Cuando se declara la invalidez, sea por un vicio de nulidad o de anulabilidad, lo que el principio de legalidad reclama y el derecho a la tutela judicial efectiva exige es que el acto se considere antijurídico desde el momento en que infringe el ordenamiento y que desde ese mismo momento se produzcan las consecuencias de la invalidez, sin perjuicio, como se verá, de las modulaciones que procedan en aplicación de otros principios del sistema. Pues en caso contrario, se llegaría al absurdo, por ejemplo, de que el particular no tendría que devolver las subvenciones recibidas ni la Administración las multas ejecutadas cuando las primeras se han otorgado o las segundas se han impuesto incurriendo en vicios de anulabilidad ${ }^{31}$.

27 Pero en este supuesto entramos ya en el terreno de las pretensiones de condena y, en casos como el referido, la anulación del acto constituye una pretensión accesoria e instrumental a la anterior, al punto que se sostiene que cuando, a pesar de las irregularidades en que incurre el acto, es posible determinar en el proceso que la Administración no tiene la obligación en la que el demandante apoya su pretensión de condena, lo procedente es que se desestime tanto la pretensión de condena como la de anulación. Sobre esto, vid. el brillante análisis de A. HUERGO LORA (2000: 262 y ss.), quien precisa que no procede la anulación, «no porque el vicio que aqueja al acto sea una mera irregularidad no invalidante (lo que probablemente sea discutible en muchos casos), sino porque el demandante no ha pedido la anulación aislada del acto (sino que ha solicitado que se condene a la Administración) y además esa anulación no favorece sus intereses puesto que no le acerca a la obtención de la prestación administrativa solicitada».

28 Sobre la invalidez formal, vid. el reciente y detallado estudio de J. GARCíA LUENGO (2016).

29 Sobre el tema, J. M. a BAÑO LEÓN (2012: 579 ss.); T. CANO CAMPOS (2012: 841 ss.). Si en el proceso se ha ejercido pretensión anulatoria de un acto denegatorio de la Administración y se ha solicitado también que se condene a la Administración a que dicte el acto estimatorio de su solicitud, cabría la retroacción de actuaciones si el órgano judicial no ha podido determinar en el proceso si el demandante tiene o no derecho a lo solicitado. En este caso, la sentencia, además de la declaración de que el acto denegatorio no se ajusta a Derecho, puede condenar a la Administración a que resuelva de nuevo la pretensión del particular. Además del trabajo citado de BAÑO, vid. A. HUERGO LORA (2000: 267, 271-272).

30 BOQUERA OLIVER, J. M. ${ }^{a}$ (1993: 115, 125); F. GARRIDO FALLA (1994: 446-447); R. ENTRENA CUESTA (1999: 226-227); J. JORDANO FRAGA (1993: 178) para quien se trata de uno de los elementos diferenciales más relevantes entre la nulidad y la anulabilidad; J. M. TRAYTER JIMÉNEZ (2015: 337). Otros autores sostienen, de forma mucho más matizada, que en el caso de la anulabilidad debe distinguirse entre actos cuya eficacia se agota en una sola aplicación (pago de una multa), en cuyo caso la eficacia de la anulabilidad será ex tunc (la cuantía de la multa debe ser devuelta), y actos cuya eficacia se extiende en el tiempo, en cuyo caso la eficacia de la anulación también será ex tunc salvo que algún principio, como el de protección de la confianza, deba ser tenido en cuenta y determine la eficacia ex nunc de la anulabilidad. Cfr. R. BOCANEGRA SIERRA (2012: 206); J. GARCÍA LUENGO (2002: 463).

$31 \mathrm{El}$ art. 36.4 de la Ley General de Subvenciones deja claro que «la declaración judicial o administrativa de nulidad o anulación de la subvención llevará consigo la obligación de devolver las cantidades percibidas». 
La Administración debe respetar el Derecho desde que actúa no desde que la Jurisdicción declara que su actuación no lo ha respetado. Si los pronunciamientos declarando la anulabilidad de un acto tuvieran efectos ex nunc, en realidad, más que de una anulación, se trataría de una revocación o de una suerte de derogación del acto. Además, ello constituiría un incentivo para que la Administración actuara contraviniendo el Derecho y calculando los beneficios que podría obtener durante el tiempo que media entre que se dicta el acto y se produce su anulación.

\section{LOS MEDIOS DE REACCIÓN CONTRA LA INVALIDEZ}

Como se ha señalado, la eficacia de los actos administrativos es independiente de su validez, por lo que, en virtud de la presunción de validez, es habitual que se produzcan efectos jurídicos no conformes a Derecho. Pero, lógicamente, el ordenamiento se preocupa de restablecer la correspondencia entre validez y eficacia y garantizar únicamente los efectos jurídicos de los actos válidos, para lo cual prevé diversos instrumentos de reacción contra los actos inválidos y atribuye a diversos órganos la competencia para su anulación.

Tales instrumentos (impugnación por los particulares ante la Administración o la Jurisdicción, acción de nulidad, revisión de oficio, revocación, etc.) son los remedios jurídicos que el ordenamiento arbitra para reaccionar contra la invalidez de los actos administrativos y los efectos que éstos hayan producido. A través de ellos, el Derecho tutela las situaciones subjetivas de los afectados por los actos inválidos o, en los supuestos de acción popular, el mero interés abstracto en la observación de la legalidad por parte de la Administración. Estos instrumentos de reacción forman parte del régimen de invalidación o anulación de los actos que incurren en vicios de nulidad o de anulabilidad. Puede decirse que constituyen el elemento dinámico de la teoría de la invalidez, pues a través de ellos se pone en marcha el funcionamiento del propio Derecho, movimiento que sólo se inicia si los particulares o la propia Administración utilizan tales instrumentos para reaccionar contra la invalidez. Si los legitimados para ello no reaccionan contra el acto inválido, el Derecho no opera y la invalidez del acto resultará irrelevante jurídicamente.

El Derecho otorga relevancia a la validez o invalidez de los actos jurídicos privando de tutela a la situación que hayan creado desde el momento en que tiene lugar la irregularidad. Así, cuando los actos, a pesar de su invalidez, ya hayan producido efectos jurídicos e incluso hayan mutado la realidad, el problema para el Derecho no es otro que el de mantener o remover la situación creada. La invalidez de los actos administrativos despliega su virtualidad funcional privando de protección jurídica a la situación creada por el acto, esto es, no tutelando el interés tendente a su mantenimiento, o, desde la otra perspectiva, prestando protección jurídica al interés que pretenda su remoción mediante el ejercicio de las acciones o recursos que procedan ${ }^{32}$. A través de las normas que regulan la invalidez se priva de protección jurídica a la pretensión sobre el mantenimiento de la situación creada por el acto y, viceversa, se otorga tutela a quien presente un interés en su remoción que el propio ordenamiento considera digno de protección ${ }^{33}$. Por eso se puede afirmar que la validez es un valor instrumental de la tutela de las situaciones jurídicas subjetivas y que la invalidez determina la ineficacia sólo a iniciativa del titular de la situación jurídica tutelada o de la propia Administración garante del interés general ${ }^{34}$.

Muy sumariamente expuestos, porque ya se ha hecho alguna referencia a ello, los medios con que cuentan los particulares y la Administración para reaccionar contra la invalidez de los actos son los siguientes.

Los particulares, tanto si se trata de actos nulos como anulables, pueden demandar la tutela de sus derechos e intereses frente al acto inválido (o pueden oponerse al cumplimiento o a la situación creada por el acto inválido) a través de los recursos administrativos y contencioso-administrativo previstos, respectivamente, en la LPAC y la LJCA. Los particulares interesados, como hemos visto, también gozan de la

32 C. S. NINO (2012: 203-207) señala que la nulidad es la negativa a prestar la coacción estatal.

33 Por eso señala E. CAPACCIOLI (1956: 110-111) que decir que un acto es inválido significa que no se puede pretender tutela en base a él y, viceversa, que se puede pretender tutela contra él. También J. A. SANTAMARÍA PASTOR (1975: 161), en su ya clásico estudio sobre la nulidad de pleno derecho, señaló que el acto inválido es el que «carece de vigor para exigir jurídicamente la realización de tales efectos típicos, y cuyos efectos eventualmente producidos de facto pueden ser eliminados mediante una acción restauradora del orden jurídico». R. BOCANEGRA SIERRA (1998: 43-44), también entiende que «lo que la invalidez produce, en cuanto sanción que el ordenamiento hace recaer sobre un acto que lo infringe, es la imposibilidad de exigibilidad jurídica de los efectos que le son propios». Vid. también T. CANO CAMPOS (2004: 194 ss.).

34 B. G. MATTARELLA (2003: 1006). 
acción de nulidad del art. 106.1 LPAC cuando el acto administrativo (favorable o desfavorable) incurre en un vicio de nulidad de pleno derecho (art. 47.1 LAP). La acción de nulidad es una suerte de tercera vía entre los recursos administrativos y la revisión de oficio que se pone en marcha a través de una solicitud ante la Administración autora del acto, que, como en la revisión de oficio propiamente dicha, es la competente para tal declaración previo dictamen favorable del Consejo de Estado ${ }^{35}$. Los particulares también pueden solicitar a la Administración, por la vía del art. 109 LPAC (pero aquí ya no gozan de una auténtica acción, sino que se limitan a ejercer su derecho de petición), la revocación de los actos anulables desfavorables, así como la de los actos originariamente válidos que han devenido inválidos como consecuencia de un cambio en las circunstancias fácticas o jurídicas que se tomaron como base o fundamento para su emanación. La impugnación o el ejercicio de la acción de nulidad pone en cuestión al acto, mientras que su anulación, o la confirmación de su validez, pone fin a la disputa acerca de su adecuación a Derecho.

La Administración, por su parte, puede acudir a la revisión de oficio, a la declaración de lesividad y a la revocación, según los casos. Si el acto es nulo de pleno derecho, la propia Administración puede declarar la invalidez mediante la revisión de oficio prevista en el art. 106 LPAC. Si el acto es anulable la Administración debe acudir al recurso de lesividad previsto en el art. 107 LPAC. Si el acto es de gravamen, la vía es la misma tanto para los actos nulos como para los anulables, y podrá revocarlo en virtud de lo dispuesto en el art. 109.1. El art. 110 LPAC, como se ha visto, establece límites materiales a todos estos poderes de revisión, haciendo ceder en vía preventiva las consecuencias de la invalidez en beneficio de las consecuencias jurídicas adecuadas a otros principios que se consideran prevalentes al principio de legalidad que es fundamento de las consecuencias de la invalidez.

La Administración también puede eliminar los vicios de los actos anulables procediendo a su subsanación. Si la Administración opta por la convalidación del acto (en los supuestos en que legalmente proceda), ello no quiere decir que aquel efecto o consecuencia de la invalidez no se produzca. Si, a pesar de la invalidez, la situación creada por el acto se mantiene es, precisamente, porque normas específicas (en nuestro caso, los arts. 52 y 119.2 LPAC) atribuyen mayor relevancia a otros hechos, en concreto a la nueva resolución de la Administración. Por consiguiente, lo que el mecanismo de la convalidación supone, en realidad, es otorgar una mayor tutela a la nueva declaración de voluntad de la Administración por la que se eliminan los vicios del acto, que a los eventuales intereses tendentes a la remoción de la situación creada por el acto inválido. Lo mismo ocurre cuando, en vía de recurso, se ordena la retroacción de actuaciones para que se subsane el vicio de forma o bien se dicta un nuevo acto sustituyendo al anterior (art. 119.2 LPAC), o cuando, en el recurso contencioso-administrativo, el Juzgado o Tribunal no se limita a anular el acto con vicios de forma sino que resuelve sobre el fondo del asunto o bien condena a la Administración a dictar un nuevo acto.

\section{LOS PRONUNCIAMIENTOS DE INVALIDEZ: ¿CARÁCTER CONSTITUTIVO O DECLARATIVO?}

Los juicios de validez (invalidez) pueden ser realizados por cualquier sujeto en diversas circunstancias, pero no cualquier juicio de validez (invalidez) tiene consecuencias jurídicas, pues el propio ordenamiento crea unos órganos específicos a los que atribuye la función de declarar la invalidez de los actos jurídicos a través de sus pronunciamientos, que son a los que, en última instancia, el Derecho reconoce efectos jurídicos ${ }^{36}$. Por ello, el que un acto (o una norma, o un contrato, etc.) sea reconocido en el seno del orde-

35 La doctrina más autorizada ha criticado -con razón- la posibilidad de una revisión de oficio a instancia del interesado y ha propuesto encaminar esta impugnación por la vía del recurso ordinario, estableciendo que los plazos no se aplicarían cuando el recurrente alegue y el órgano de resolución aprecie la concurrencia de un vicio de nulidad de pleno derecho. Vid. J. A. SANTAMARÍA PASTOR (2016b: 268), S. MUÑOZ MACHADO (2018: 179). Críticos también con la regulación actual, que mantiene «idéntico desbarajuste» que la Ley 30/1992, M. REBOLLO PUIG y E. CARBONELL PORRAS (2018: 178).

36 El juicio de validez (invalidez) puede ser realizado por diversos órganos o sujetos: por la Jurisdicción al entender de un recurso contencioso-administrativo o por la Administración al ejercer la revisión de oficio, pronunciarse sobre la acción de nulidad ejercitada o resolver un recurso administrativo; por un abogado o por un particular para que se declare la invalidez; por un jurista que describe el ordenamiento, comenta una sentencia, etc.; por cualquier persona al expresar su propio juicio sobre la adecuación de un acto al ordenamiento jurídico. En el primer supuesto (pronunciamiento del Juez o de la Administración), el juicio de validez es pronunciado desde el punto de vista interno y es el que tiene realmente efectos jurídicos al anular el acto; en los demás, el juicio se realiza desde del punto de vista externo y carece de consecuencias jurídicas (salvo la incidencia que en el parecer de la Jurisdicción o de la Administración pueda tener en el futuro la opinión de la dogmática jurídica, la cual, además de una función ordenadora y sistematizadora, realiza una verdadera función normativa). Sobre los referidos juicios de validez, vid. GUASTINI (1999: 388 y sS.); R. LETELIER WARTENBERG 
namiento jurídico como válido o inválido depende del pronunciamiento autoritativo de ciertos órganos, los cuales, como es evidente, deben realizar tales pronunciamientos atendiendo a que se hayan cumplido o no las condiciones que el Derecho establece como requisitos de su validez, pero a los que, en último término, el ordenamiento reconoce efectos con independencia de su corrección ${ }^{37}$. En el mundo del Derecho la discusión abierta tiene que cerrarse en algún momento mediante una decisión de autoridad, por alguien que tenga la última palabra, pero esta decisión se ve permeada por exigencias de racionalidad cada vez mayores a través de la motivación de las decisiones ${ }^{38}$.

La anulación es un acto -administrativo o jurisdiccional- por el que se declara con carácter imperativo y erga omnes la invalidez de un acto, momento a partir del cual el Derecho priva de tutela a la situación creada por el acto y éste deja de producir efectos pro futuro ${ }^{39}$. Suele ser habitual sostener que los pronunciamientos (resoluciones administrativas o sentencias) de nulidad tienen carácter meramente declarativo mientras que los de anulabilidad son constitutivos. Pero esta distinción parte de un falso presupuesto, no tiene relevancia y, además, creo que es errónea.

Parte del presupuesto de la ineficacia ab initio e ipso iure de los actos nulos, por lo que una eventual sentencia sólo tendría efectos declarativos; por el contrario, como los actos anulables serian válidos y producirían efectos hasta que fueran anulados, y la anulabilidad, por ello, debería ser acordada por el Juez o por la Administración, el pronunciamiento tendría efectos constitutivos. Pero, como se ha visto, los actos nulos, como los anulables, se presumen válidos y son eficaces desde que se dictan, por lo que en ambos casos es preciso el pronunciamiento de un sujeto autorizado anulando el acto. Hay que tener en cuenta, por otra parte, que cuando alguien pretende que se declare la invalidez de un acto es porque se está viendo perjudicado por una situación jurídica que quiere modificar mediante el pronunciamiento que lo anula y volver así una situación acorde a sus intereses. Con el pronunciamiento autoritativo de nulidad no se pretende adjetivar el acto: declarar sin más que un acto es nulo es como declarar que es alto, corto o amarillo ${ }^{40}$. Pretender la nulidad es pretender la no tutela o protección de la situación creada por un acto del que la otra parte (la Administración u otro sujeto al que el acto favorece) defiende su eficacia y validez.

La distinción, en segundo lugar, no tiene relevancia porque carece de efectos prácticos: si se impugna un acto inválido pero la impugnación no prospera, el acto seguirá produciendo efectos como si fuera válido, tanto si incurre en un vicio de nulidad como si el vicio que padece es de anulabilidad; y si la impugnación del acto prospera, las consecuencias serán las mismas tanto si es nulo como si es anulable: se negarán sus efectos para el futuro y no se protegerá la situación creada. Es una distinción, además, que no está en la LJCA, que sería su sede natural. El art. 71.1.a) de la LJCA se limita a disponer que, de estimarse el recurso, la sentencia «anulará» el acto, y el art. 72.2 añade que la «anulación» de una disposición o acto producirá efectos para todos los afectados, de modo que se prevé el mismo régimen y se establecen los mismos efectos generales de las sentencias de anulación. Los órganos de esta Jurisdicción anulan tanto actos nulos como actos anulables.

Y la distinción, en fin, es errónea porque está mal planteada. En vez de diferenciar entre pronunciamientos de nulidad y de anulabilidad, hay que distinguir entre el contenido de la decisión (administrativa o judicial) declarando la invalidez (porque concurre un vicio relevante) y los efectos que produce esa decisión. Una

(2011: 93-94). Vid. también, F. RUBIO LLORENTE (1990: 25): la invalidez puede «ser apreciada, sin que esta apreciación tenga consecuencias normativas, también por la doctrina». A. NIETO GARCÍA (1994: 10-11, 21-22), para diferenciar el plano interno y el externo distingue entre ilegalidad (juicio que puede realizar cualquiera y es el resultado de una constatación) e invalidez (juicio que sólo pueden realizar determinados órganos y es el resultado de una valoración o calificación jurídica sobre el alcance de la ilegalidad), a la que define como «la declaración de ilegalidad relevante realizada por el órgano constitucionalmente legitimado para ello».

${ }^{37}$ M. ATIENZA RODRÍGUEZ y J. RUIZ MANERO (2003: 725-726).

38 M. ATIENZA RODRÍGUEZ y F. LAPORTA (2009: 221).

${ }^{39}$ En algunos supuestos, se realiza un juicio relevante de invalidez pero el acto no se anula. Por ejemplo: cuando se sanciona a un funcionario por la adopción de «acuerdos manifiestamente ilegales», cuando en los conflictos de competencia se declara la incompetencia de una Administración al dictar un acto y por tanto su ilegalidad o cuando se aprecia la responsabilidad patrimonial de la Administración por un acto administrativo ilegal. En tales casos, el Derecho sólo exige un pronunciamiento de invalidez desde el punto de vista del antecedente o condiciones (de los vicios de validez), no desde el consecuente o los efectos propios de la invalidez, porque las consecuencias que tales normas prevén son distintas a la anulación: imposición de una sanción, determinación de la Administración competente, declaración de responsabilidad. El órgano de que se trate es competente para apreciar la invalidez del acto pero no para declarar su nulidad. M. REBOLLO PUIG (2005: 596-601), de quien proceden los ejemplos, distingue en tales casos entre ilegalidad e invalidez y concluye que lo que se destruye es la presunción de legalidad, pero no la de validez. Sobre el tema, más ampliamente T. CANO CAMPOS (2016: 1874-1876). También alude a que en ocasiones la declaración de invalidez no arrastra la nulidad, A. NIETO GARCíA (1994: 22, 24) para quien ello «resulta explicable desde un punto de vista competencial».

40 M. PASQUAU LIAÑO (2007: 237). 
cosa es el contenido de un pronunciamiento y otra los efectos que las normas jurídicas le atribuyen. Esta distinción permite aclarar, con carácter general, que también las decisiones puramente declarativas pueden tener efectos jurídicos ${ }^{41}$. De este modo los pronunciamientos de invalidez de los actos o de las normas tienen un doble carácter: desde el punto de vista de su contenido son declarativos de una realidad jurídica anterior porque constatan y declaran una antijuridicidad o irregularidad ya existente: que el acto incurre en un vicio de nulidad o de anulabilidad. Pero desde la perspectiva de los efectos que producen son constitutivos de una realidad jurídica nueva, pues destruyen la presunción de validez del acto, le privan de efectos y no otorgan tutela a la situación que han creado, la cual, si ningún principio del sistema lo impide, debe ser restablecida de inmediato.

\section{LA SITUACIÓN CREADA POR LOS ACTOS INVÁLIDOS Y SU PROTECCIÓN}

Pero, ¿por qué a veces se mantienen los efectos de los actos inválidos y parece, por ello, que la invalidez no tiene esas consecuencias? Porque cuanto más tarde en llegar la declaración de invalidez más difícil será el restablecimiento de la legalidad alterada, ya que los efectos producidos por el acto se habrán integrado en el tráfico jurídico y habrán servido de base a otros actos, los cuales, a su vez, habrán creado nuevas expectativas y derechos a otros sujetos ${ }^{42}$. Por eso, la privación de tutela a la situación creada por el acto anulado no operará en el vacío o de forma aislada, sino sobre una realidad fáctica y jurídica que se habrá creado al socaire del acto irregular y que también reclamará del Derecho tutela o protección. Y por eso, también, un adecuado diseño del procedimiento y de los recursos administrativos (y jurisdiccionales) resultan esenciales para garantizar una reacción eficaz frente a la invalidez, como se puede apreciar perfectamente en el ámbito de los contratos públicos ${ }^{43}$.

La situación creada por el acto es un nuevo hecho. Un nuevo hecho que puede generar la aplicación de nuevo Derecho confirmando dicha situación. Así, principios como el de seguridad jurídica, protección de la confianza, prohibición de enriquecimiento o continuidad de los servicios públicos, pueden resultar ahora de aplicación y amparar jurídicamente la situación que se haya creado como consecuencia de un acto que procede anular. Pues bien, son tales principios, y no el acto inválido, los que explican que en determinados supuestos se mantengan los efectos producidos y queden liberados de cualquier reparo jurídico.

Tales principios se imponen, tras una ponderación con el principio -derivado del de legalidad- que establece la no tutela de los efectos del acto anulado, y por ello amparan el mantenimiento de esos mismos efectos o de otros efectos parcialmente distintos (por ejemplo, una indemnización mayor al justiprecio en una expropiación declarada nula, o una indemnización por un valor mayor que el de restitución).

Por lo general, esta operación tiene lugar en el proceso de control de la validez del acto. Pero hay veces que la ponderación no la hace el Juez o la Administración en el caso concreto, sino que la realiza de forma abstracta el propio legislador, el cual antepone los intereses protegidos por la seguridad jurídica o el interés general a los que atiende la invalidez y, en atención a ello, determina los efectos que ha de tener la declaración de nulidad o, incluso, impide que dicha declaración tenga lugar.

Un ejemplo de lo primero puede verse en el art. 73 LJCA, que dispone prima facie el mantenimiento de los actos administrativos firmes dictados en aplicación de reglamentos declarados nulos, salvo que se trate de sanciones no ejecutadas ${ }^{44}$. Lo segundo tiene lugar en previsiones como la del antiguo art. 38 del Texto

41 R. GUASTINI, (2010: 386), quien pone el ejemplo de las sentencias estimatorias del TC y señala que, desde el punto de vista de su contenido no constituyen sino que declaran la inconstitucionalidad, pero, al mismo tiempo, la sentencia es constitutiva de los efectos que produce: generalmente, la eliminación e inaplicabilidad de la ley (pág. 386). Vid. también, R. GUASTINI, (2013: 129), donde señala que dicha distinción está implícita en la importante obra de ALCHOURRÓN y BULYGIN, Normative System de 1971 (edición española de 1975). Hay una segunda edición revisada: C. E. ALCHOURRÓN y E. BULYGIN, (2015: 208-211). Estos autores, en efecto, distinguen entre decisiones declarativas (cuyo contenido es un enunciado clasificatorio o subsuntivo; por ejemplo: T es un testamento válido, J está en quiebra) y decisiones normativas (que establecen una prescripción: P debe ser castigado, el local debe ser desalojado), las cuales pueden concurrir en una misma decisión.

42 R. LETELIER WARTENBERG (2011: 176); S. DÍEZ SASTRE (2012: 74).

43 S. DÍEZ SASTRE (2017: 303 y ss.).

44 Este precepto no establece que tales actos sean válidos, sino que la declaración de nulidad de la disposición general en virtud de la cual tales actos han sido dictados no afectará per se a su eficacia, lo que, en rigor, ni siquiera impide el que tales actos puedan ser revisados ulteriormente. Sobre el tema, M. REBOLLO PUIG (1998: 533); G. DOMÉNECH PASCUAL (2002: 342-343); J. A. SANTAMARÍA PASTOR, B. LOZANO CUTANDA, J. P. QUINTANAR CARRETERO, R. CASTILLO BADAL (2014:704). Lo mismo puede afirmarse respecto de la previsión del art. 106.4 LPAC. 
refundido de la Ley de Contratos del Sector Público de 2011, que habilitaba al órgano competente para declarar la nulidad de un contrato inválido a que no la declarase y acordase el mantenimiento de sus efectos si concurren razones imperiosas de interés general. En estos casos, los efectos que se mantienen no encuentran cobertura en el reglamento anulado o en el contrato inválido cuya nulidad ni siquiera se llega a declarar, sino en el principio de seguridad jurídica, en el primer caso, y en las razones imperiosas de interés general que en cada caso concurran y que recoge ya expresamente el propio legislador sin remitir su apreciación al proceso de control, en el segundo. Los límites a las facultades de revisión previstas en el actual art. 110 LPAC también hallarían su explicación en el hecho de que el principio de no tutela de la situación creada por los actos inválidos cede (aquí también en vía preventiva, impidiendo incluso la anulación del acto por parte de la Administración) ante la concurrencia de otros principios jurídicos de obligada observancia, como la protección de la buena fe, la confianza legítima o la equidad, que resultan de aplicación a la situación creada por el transcurso del tiempo.

La concurrencia y aplicación de estos principios amparan o protegen la situación generada en torno a un acto inválido. Pero, como adelanté, tales principios no convierten al acto en válido o conforme a Derecho, pues el ordenamiento no los configura como requisitos de validez. Creo que conviene insistir en esto porque con ello se destaca que la Administración nunca debió dictar el acto y que no puede hacerlo contraviniendo las normas que regulan su forma de producción. En el plano doctrinal, y desde el punto de vista externo, esto permite la crítica por parte de la dogmática jurídica y tiene incluso un efecto pedagógico sobre la propia Administración pública de cara a su actuar futuro.

Por otra parte, los principios que tutelan la situación creada por el acto inválido deberían aflorar, en la medida de lo posible, en el proceso declarativo y no en el proceso ejecutivo ulterior cuando se analiza el alcance de los efectos de la nulidad ya declarada. Se evitaría así que en la fase de ejecución de la sentencia emerjan principios que ya estaban presentes pero no habían ingresado en la discusión inicial ${ }^{45}$.

Además, en mi opinión, el juez no debería ser el «dueño y señor» de la ponderación, sino que el legislador debe establecer criterios sobre cuándo procede realizarla, como hace, por ejemplo, en relación a los actos firmes o cuando establece límites a la revisión de oficio. Así lo impone el imperio de la Ley.

\section{TIEMPO Y VALIDEZ: LA INVALIDEZ SOBREVENIDA}

Paso, por último, a analizar las complejas relaciones entre tiempo y validez. Hay quien sostiene que el momento decisivo para enjuiciar la validez de un acto es el momento en que se dicta (tempus regit actum). Un cambio ulterior en las circunstancias fácticas o jurídicas, se afirma, no puede convertir en inválido a un acto que nació conforme a Derecho, de modo que ya no afectará a su validez sino, si acaso, a su eficacia o a las relaciones jurídicas que haya creado ${ }^{46}$.

Pero la invalidez sobrevenida es una figura admitida en la teoría general del Derecho y en el propio Derecho Constitucional ${ }^{47}$. En el Derecho Administrativo, algunos autores y el propio Consejo de Estado la han utilizado para explicar dogmáticamente diversas figuras como la reversión en la expropiación forzosa o la revocación de las autorizaciones por la desaparición de las circunstancias exigidas para su otorgamiento ${ }^{48}$. La jurisprudencia, además de en esos supuestos, también la ha utilizado para enjuiciar la validez de la eje-

45 R. LETELIER WARTENBERG (2011: 389-395). R. GÓMEZ-FERRER RINCÓN (2008: 271 nota 14, 311 nota 36, 363, 379) señala, con razón, que, del mismo modo que la construcción de una obra pública se tiene en cuenta al declarar la ilegalidad de la expropiación, en el resto de supuestos, las circunstancias de hecho y de derecho que impiden la ejecución de la sentencia (por ejemplo un cambio de planeamiento en las licencias urbanísticas) deberían ser tenidas en cuenta al dictarse ésta y no remitirse, como hace el juzgado, al momento de su ejecución.

46 Entre los más firmes defensores de esta idea pueden destacarse, R. BOCANEGRA SIERRA (2005: 81) y (2012: 80-81); J. M. ALEGRE ÁVILA (2012: 492 ss.). También se opone a la utilización del término, aunque reconoce que su discrepancia con quienes aceptan la figura es más bien terminológica, V. S. BACA ONETO (2006: 45 ss.), que habla de ilegitimidad (entendida como la falta de cobertura jurídica de los efectos de un acto) sobrevenida y la predica de las situaciones o relaciones jurídicas que el acto ha creado.

47 Vid., entre otros muchos, M. GASCÓN ABELLÁN, (1994: 857-858); R. GUASTINI (2010: 263-264); L. PAREJO ALFONSO (1981: 201 ss.); L. M. ${ }^{a}$ DÍEZ-PICAZO (1990: 310); J. JIMÉNEZ CAMPO (1998: 112, 115 ); A. GARRORENA MORALES (1999: 349); A. J. GÓMEZ MONTORO (2001: 581); I. DE OTTO Y PARDO (2010: 686); S. MUÑOZ MACHADO (2015: 236). También la admiten, para las leyes, numerosas sentencias del TC: 4/1981 y 11/1981, 83/1984, 126/1997, 159/2001, 10/2002, 224/2006, 166/2014, 195/2015, 98/2016, 102/2016, etc.

48 E. GARCÍA DE ENTERRÍA (1984: 140); J. M. SALA ARQUER (1974: 43). Vid. los Dictámenes del Consejo de Estado núms. $567 / 1991$, de 24 de abril de 1991 y 1641/95, de 20 de julio de 1995, entre otros. 
cución de un retracto forestal ${ }^{49}$. Un autorizado y amplio sector doctrinal también ha sostenido, con carácter general, que la invalidez sobrevenida es una figura que explica adecuadamente algunos fenómenos jurídicos, tiene un indudable fondo de verdad, responde a problemas reales y pone de manifiesto la concepción dinámica del principio de legalidad ${ }^{50}$.

La invalidez sobrevenida no es un concepto ilógico, erróneo o contradictorio, como algunos afirman. Claro: a menos que se asuma o estipule un concepto de invalidez en el que los vicios de los actos deban concurrir, por definición, en el momento en que se dictan. Al fin y al cabo, cada concepto implica lo que se haya incluido en él al definirlo. Yo, sinceramente, no veo ningún reparo dogmático a la posibilidad de que un acto administrativo devenga antijurídico y, por ello, inválido como consecuencia de un cambio de las circunstancias de hecho o de Derecho que se tomaron como base o fundamento cuando se dictó ${ }^{51}$. Cuando cambian o se alteran los presupuestos de hecho o de Derecho que sirvieron de base para dictar el acto, la valoración que la Administración realizó al dictarlo no se vuelve errónea, pero, debido al desarrollo de las circunstancias, el acto presenta ahora un contenido que ya no se adecua al Derecho actualmente en vigor.

La principal crítica que se hace a la posibilidad de una invalidez sobrevenida de los actos administrativos reside en que éstos, en cuanto que resolución productora de efectos jurídicos para un caso concreto, son instantáneos, momentáneos o fugaces, de modo que, una vez dictados, desaparecen y sólo permanecen las situaciones o relaciones jurídicas que han creado ${ }^{52}$. Pero esto, según creo, carece de fundamento porque no tiene en cuenta que el acto administrativo (al igual que una ley, un contrato o una sentencia) constituye el ejercicio de acciones institucionales (que en cuanto tales son momentáneas o instantáneas: también lo es el acto de aprobar una ley o dictar una sentencia) que dan lugar a resultados institucionales, y que si perduran los efectos o la relación jurídica que dicho resultado institucional ha creado es porque el acto, como resultado institucional que es, permanece y las ampara hasta que el propio acto no sea anulado, revocado, etc. ${ }^{53}$

El acto administrativo no se extingue una vez dictado ni desaparece cuando se cumple o ejecuta, sino que pasa a formar parte del sistema jurídico, no a los efectos de poder ser objeto de aplicaciones reiteradas o sucesivas (ya que, por definición, carece del requisito de la abstracción, y en esto se diferencia de los regla-

49 Las sentencias que explican la reversión en la expropiación con la teoría de la invalidez sobrevenida son muy numerosas [vid., por ejemplo, las SSTS de 1 de diciembre de 2011 (recurso de casación núm. 3023/2008), de 7 de octubre de 2013 (recurso de casación núm. 247/2011), de 17 de abril de 2015 (recurso de casación núm. 4251/2012), de 21 de noviembre de 2015 (recurso de casación núm. 3414/2013)]. Esta explicación es compartida por la mayoría de la doctrina, pero también ha sido cuestionada por algunos autores. Vid., por ejemplo, J. M. ALEGRE ÁVILA (1993: 229 y ss.) y, más recientemente, respecto del incumplimiento del deber de afectación, D. UTRILLA FERNÁNDEZ-BERMEJO (2015: 263) que, para ese concreto supuesto señala, probablemente con razón, que «el gravamen de afectación no es un elemento de validez, sino un efecto del acto administrativo expropiatorio», por lo que «su eventual incumplimiento no podrá proyectarse sobre el plano de la validez del acto, sino a lo sumo, sobre el de su eficacia». Sobre la aplicación de la teoría de la invalidez sobrevenida a la ejecución de un retracto forestal por pérdida sobrevenida de la causa, vid. la importante STS de 21 de marzo de 2011 (recurso de casación núm. 5596/2006), donde se señala que la validez del acto (en concreto la adecuación de su contenido a la finalidad pública que prevé la norma atributiva de la potestad) no sólo debe concurrir cuando se dicta el acto sino también durante el tiempo que despliega sus efectos, singularmente cuando ha de ejecutarse materialmente. Vid. los comentarios a dicha sentencia de C. CHINCHILLA MARÍN (2011: 7 ss.), J. A. CARRILLO DONAIRE (2012: 209 ss.), T. CANO CAMPOS (2011: 50 ss.).

50 L. COSCULLUELA MONTANER (2016: 373-374); G. FERNÁNDEZ FARRERES (2018: 808-809); M. REBOLLO PUIG, (2018: 119-120); E. GAMERO CASADO y S. FERNÁNDEZ RAMOS (2016: 530); A. BUENO ARMIJO (2011: 211). La admite, aunque estableciendo un campo de aplicación distinto ya que considera que sólo hay invalidez sobrevenida cuando «el desajuste entre el acto y la norma es imputable a la Administración», D. BLANQUER CRIADO (2014: 1309 ss.). También da cuenta de la teoría y la admite F. GARRIDO FALLA (1994: 496).

51 T. CANO CAMPOS (2004: 69 ss.), donde se analiza el surgimiento de la teoría de la invalidez sobrevenida (págs. 33 y ss.), su funcionalidad y utilidad en nuestro sistema (págs. 143 y ss.), los supuestos en que un acto puede devenir inválido (224 y ss.) y los instrumentos para hacerla valer (326 y ss.).

52 V. S. BACA ONETO (2006: 45-46). Otros autores, como J. M. ALEGRE ÁVILA (2012: 494-495) sostienen que «la validez es el necesario punto de inserción del acto en la vida jurídica» y «una vez producida esta inserción, toda la dinámica del acto ha de enfocarse exclusivamente desde la perspectiva de la eficacia».

53 Las acciones y los resultados institucionales son aquellos que no son posibles en ausencia de reglas constitutivas, es decir, de reglas que crean la posibilidad de dichas acciones y resultados. Así, por ejemplo, mientras que acciones y resultados como matar y estar muerto son posibles en ausencia de regla alguna, y el concepto no depende de ninguna regla, acciones como aprobar una ley, celebrar un contrato o dictar una sentencia o un acto y sus correspondientes resultados (ley, contrato, sentencia, acto) solo son posibles de acuerdo con reglas del referido tipo, en concreto de las reglas constitutivas que confieren poderes (lo que entre nosotros conocemos como normas de competencia). Vid. M. ATIENZA y J. RUIZ MANERO (2003: 719); J. A. PÉREZ LLEDÓ (2015: 28 ss.). Por eso, en el ámbito jurídico, la validez es una cualidad que se puede predicar de distintas acciones y resultados institucionales: de las normas, de los actos jurídicos que las aplican (actos administrativos, actos procesales, etc.), de los actos de autonomía privada (contratos, testamentos, donaciones, etc.) o de cláusulas particulares de tales actos (cláusulas contractuales, testamentarias, accesorias). Vid. R. GUASTINI (1999: 319). Un esquema ordenado de todo aquello que puede ser calificado como válido o inválido, en M. ATIENZA y J. RUIZ MANERO (2003: 722). 
mentos), sino a los efectos de reconocer, proteger y amparar la situación o relación jurídica que ha creado ${ }^{54}$. Como resultado institucional que es, el acto administrativo sigue «existiendo» una vez dictado y continua siendo relevante para el Derecho desde numerosos aspectos, incluso cuando se ha cumplido o ha sido ejecutado. Esto tiene lugar no sólo en el caso de los actos denominados de estatus, como los que otorgan la nacionalidad, nombran a un funcionario o califican un bien (por ejemplo, como demanial), sino también cuando se trata de actos con efectos indefinidos (por ejemplo, una licencia de obras, que ampara de forma indefinida el edificio construido) o, incluso, cuando se trata de actos que se agotan o consumen con su cumplimiento o ejecución (por ejemplo, una sanción ya pagada sigue siendo relevante a los efectos de que no pueda de nuevo exigirse el pago, de beneficiarse de una norma retroactiva in bonus si a pesar de que se pagó se recurrió y el recurso no ha sido resuelto o, bien, de ser tenida en cuenta a efectos de aplicar la agravante de reincidencia).

La tesis de la instantaneidad del acto se ve contradicha, por lo demás, por los propios usos lingüísticos y, lo que es más importante, por el propio Derecho positivo que regula infinidad de instituciones o figuras referidas al acto administrativo y no sólo a sus efectos o a las relaciones que ha creado: la impugnación del acto por los particulares, la revisión de oficio y la revocación por la Administración, la conservación, la convalidación, la conversión, la anulación, etc. Por otra parte, y aunque esto requeriría un análisis y una reflexión mucho más profunda, la discusión acerca de la instantaneidad o no del acto administrativo quizá se deba a que no se tiene en cuenta que, en realidad, el acto (como el resto de resultados institucionales: sentencia, contrato, matrimonio, etc.) no es sino una forma abreviada de referirse a ese complejo conjunto de derechos, permisos, obligaciones, situaciones, relaciones, calificaciones, etc., que forman su contenido bajo una determinada forma o vestidura formal ${ }^{55}$.

La visión de la validez desde el punto de vista de los denominados elementos del acto no desmiente la tesis de que pueden incurrir en invalidez sobrevenida, pues algunos de ellos como el presupuesto de hecho puede alterarse o desparecer y otros como el contenido del acto puede devenir contrario a Derecho.

Por lo demás, la teoría de la invalidez sobrevenida no niega, como algunos parecen entender, que el acto originariamente conforme a Derecho siga siendo un precedente válido a la hora de valorar (por ejemplo, desde la perspectiva del principio de igualdad) las demás aplicaciones, futuras o pasadas, de la normativa que lo justificó ${ }^{56}$. En la medida en que la invalidez sobrevenida y sus consecuencias no se producen desde que el acto se dictó, sino desde que éste realmente deviene contrario al ordenamiento, la aplicación inicial de la normativa que justificó el acto es válida o conforme a Derecho (por eso se protegen y mantienen los efectos del acto durante ese tiempo), por lo que puede seguir siendo un precedente legítimo o adecuado de las demás aplicaciones, futuras o pasadas, que tengan como base o fundamento las circunstancias fácticas y jurídicas que concurrieron en aquel momento inicial en el que el acto fue dictado.

Las consecuencias de la invalidez sobrevenida difieren de las de la originaria desde el punto de vista temporal, pues aquéllas tienen lugar no desde que el acto se dictó, sino desde que devino contrario a Derecho por un cambio en las circunstancias fácticas o jurídicas que le sirvieron de fundamento. Si la invalidez se produce una vez dictado el acto pero se retrotrae al momento en el que se dictó, estaremos ante una acto administrativo originariamente inválido ${ }^{57}$.

En definitiva, en mi opinión la invalidez sobrevenida no encuentra obstáculos dogmáticos insalvables, como se pretende, y, sobre todo, es una categoría útil porque sirve para explicar determinados fenómenos jurídicos y resolver algunos problemas. Pero son dudosos y discutidos los supuestos en los que procede

54 R. BOCANEGRA SIERRA (2012: 139): «agotado su efecto principal, el acto administrativo continúa, sin embargo, teniendo existencia jurídica»; R. LETELIER WARTENBERG, (2011: 58): «En verdad, los actos administrativos se incrustan en el sistema jurídico, pues reconocen y protegen, sin límite temporal, la situación jurídica que han creado».

55 Vid. J. PÉREZ LLEDÓ (2015: 40-41): un resultado institucional «es en realidad una forma abreviada, más "económica" para referirse a ciertas consecuencias normativas que el ordenamiento liga al hecho de que se hayan dado las condiciones del antecedente... un "matrimonio" no es más que una forma abreviada de referirse, sin tener que detallarlas explícitamente, a un complejo de derechos y deberes que surgen (entre los cónyuges, hacia terceros, hacia la Administración, etc.) ... el matrimonio es ese mismo conjunto de derechos y deberes». A esto parecen apuntar también G. DOMÉNECH PASCUAL (2002: 208) cuando afirma que el objeto del que se predica la validez o invalidez es el contenido del reglamento, y R. LETELIER WARTENBERG (2011: 43) al señalar que «la premisa de que los actos jurídicos no son sino sus efectos no puede ser ignorada». De hecho, la mayor parte de los denominados elementos del acto lo son de las normas que confieren la potestad y regulan su concreto ejercicio o de otras normas del sistema.

56 Cfr. R. BOCANEGRA SIERRA, (2005: 82) y (2012: 81), donde habla de que el acto ha devenido inoportuno.

57 Vid. H. MAURER (2011: 305): «hay que diferenciar de este caso [actos que originariamente eran conformes a Derecho pero que por un cambio de las circunstancias se convirtieron en ilegales] el del acto administrativo cuya ilegalidad se produce tras su emisión pero que se extiende retroactivamente al momento en el que se dictó; en este caso, estamos ante un acto administrativo antijurídico desde el inicio al que se aplican las normas propias de la revisión de oficio». Vid. también T. CANO CAMPOS (2004: 224-226). 
hablar de ella; $y$, sobre todo, carecemos de los medios adecuados para reaccionar contra un acto originariamente válido que después deviene contrario a Derecho.

Desde el punto de vista de los supuestos, la invalidez sobrevenida debe reservarse exclusivamente a aquellos casos en los que realmente haya un cambio sobrevenido de las circunstancias de hecho o de Derecho que sirvieron de base o fundamento para dictar el acto. Lo que impide, por ejemplo, que pueda hablarse de invalidez sobrevenida cuando se incumple una obligación, un modo o una carga que impone el propio contenido del acto, pues su cumplimiento no pudo servirle de soporte en su momento y por ello su incumplimiento no puede hacer que devenga inválido, como se ve claramente en el caso de las subvenciones que no se emplean conforme al fin que fundamenta su otorgamiento. Se debe plantear hipotéticamente si, según las circunstancias de hecho o de Derecho que ahora concurren, la Administración pública estaría obligada o, en caso de que pueda actuar de forma discrecional, habilitada a dictar el acto administrativo de que se trate. Si en atención a las nuevas circunstancias fácticas y jurídicas ahora no fuera posible (jurídicamente) dictar ese mismo acto administrativo, puede concluirse que el acto ha devenido inválido. Esto puede ocurrir, singularmente, en los actos con efectos prolongados en el tiempo (una concesión demanial, una autorización de funcionamiento, autorizaciones personales como el permiso de armas o el de conducir, una prohibición para realizar una determinada actividad, etc.), aunque no sólo en ellos ${ }^{58}$. El campo de la gestión de los riesgos es un sector de referencia importante en este ámbito, pues las circunstancias fácticas de las que depende el acto administrativo (normalmente autorizaciones) puede cambiar como consecuencia del progreso científico y el avance del conocimiento, por lo que debe preverse la posibilidad de modificación o revocación para dejar abierto el contenido de la decisión administrativa al avance del conocimiento ${ }^{59}$.

Pero el verdadero problema reside en las vías de reacción contra la invalidez sobrevenida, porque la regulación vigente está claramente orientada hacia los actos administrativos originariamente inválidos. Durante la tramitación de la Ley 30/1992 se presentó una enmienda que preveía la revocabilidad de los actos favorables por razones de ilegalidad sobrevenida. Pero la propuesta no prosperó a pesar del juicio favorable del Consejo de Estado ${ }^{60}$. La nueva LPAC ni se lo plantea y deja todo como estaba. ¡Al menos no lo ha empeorado! Como en tantas otras cuestiones, no se ha aprovechado la ocasión para introducir en nuestro ordenamiento una regulación más completa y detallada de la revocación de las decisiones administrativas, en función de que sean inicialmente conformes o no a Derecho. La regulación de la revocación en Alemania o la propuesta del Código ReNUAL de procedimiento administrativo de la UE, podrían haber servido de modelo u orientación a nuestro legislador.

La revocación, en efecto, parece la figura más adecuada para reaccionar contra los actos administrativos que devienen inválidos, pues el establecimiento de plazos preclusivos dificulta la utilización de los medios impugnatorios contra tales actos, no sólo porque los breves plazos para recurrir se computan desde que el acto se notifica, y no parece probable que la Administración vaya a informar a los interesados de los vicios sobrevenidos que detecte, sino también porque, en numerosos supuestos, el acto administrativo habrá devenido inválido como consecuencia de una infracción duradera que no pierde gravedad con el paso del tiempo (piénsese en una autorización para comercializar una especialidad farmacéutica o un producto peligroso) ni es capaz de generar una confianza legítima en las personas a las que favorece que justifique su conservación una vez transcurrido un tiempo desde que se tornó inválido ${ }^{61}$.

58 Como se ha visto, la STS de 21 de marzo de 2011 (recurso núm. 5596/2006) lo aplica a un acto administrativo que se consume con su cumplimiento o con su ejecución, precisamente porque cuando se pretendía ejecutar varios años después habían cambiado las circunstancias fácticas y el contenido del acto ya no se adecuaba a la finalidad de la norma atributiva de la potestad para ejecutar el retracto forestal.

59 Como señala J. M. a RODRÍGUEZ DE SANTIAGO (2016: 55) «la gestión jurídico-administrativa de la inseguridad fáctica eventualmente dañosa tiene que desplazar la idea clásica, vinculada al principio de seguridad jurídica (art. $9.3 \mathrm{CE}$ ), del acto administrativo como decisión estable y tendencialmente inmodificable, adoptada como consecuencia de una fijación de hechos que se considera definitiva». Los elementos fácticos juegan un importante papel en la invalidez del acto y son, con frecuencia, el problema principal y más discutido. Sobre ello, H. MAURER (2011: 256); M. REBOLLO PUIG (2018: 101).

60 El Dictamen 1076/1991, de 31 de octubre, sobre el Anteproyecto de LRJPAC, señaló lo siguiente: «Al margen de las tradicionales disputas terminológicas y conceptuales, habría que plantearse la eventual conveniencia de introducir en el Anteproyecto una regulación de la revocación y de la anulación (para algunos revocación) por ilegalidad sobrevenida, figuras respecto de las que se ha destacado la falta de una previsión general y expresa en la Ley de Procedimiento Administrativo (aunque algunos vestigios haya en su Exposición de Motivos y en el artículo 112). De esta regulación serían parte central los supuestos de revocación (o de revisión) y las garantías de los interesados (audiencia, intervención del Consejo de Estado y régimen de indemnización en su caso».

61 G. DOMÉNECH PASCUAL (2005: 504). También M. REBOLLO PUIG, (2018: 119), considera difícil admitir que se reabran los plazos para interponer los recursos a partir del momento en que se sobreviene la ilegalidad. 
Hay que acudir, por ello, a la vía de la revocación (o la modificación, que se considera generalmente como una revocación parcial ${ }^{62}$. Pero, por la razón ya apuntada, la regulación de la LPAC presenta en esto un déficit considerable. Hay que tener presente, además, que, en ocasiones, ciertos principios institucionales del sistema pueden operar en vía preventiva o ex ante impidiendo, en aplicación del art. 110 LPAC, la revocación de un acto que ha devenido inválido.

Si se trata de actos favorables, podría admitirse, como hacen algunas leyes sectoriales [art. 65.1 del Texto Refundido de la Ley de Aguas, art. 77.a) y c) de la Ley de Costas, art. 73.6 Ley de Hidrocarburos, art. 70 del Texto Refundido de la Ley de Tráfico y Seguridad Vial], su revocación por la Administración tras valorar en qué medida el mantenimiento del acto perjudica los intereses generales, indemnizando los daños causados cuando fuera procedente; pro ejemplo si la Administración ha cambiado las normas que sirvieron de parámetro de validez ${ }^{63}$. En el caso de los actos desfavorables, la Administración puede acudir a la vía que le ofrece el art. 109 LPAC, pues, si en virtud de dicho precepto la Administración puede revocar sus actos desfavorables o de gravamen, y puede hacerlo tanto por razones de oportunidad como de legalidad, también podrá hacerlo cuando la ilegalidad sea sobrevenida ${ }^{64}$.

En el caso de los particulares, habría que admitir que pudieran solicitar a la Administración la revocación del acto que haya devenido inválido. La revocación debería ser obligatoria para la Administración a partir del momento en el que hayan cambiado las circunstancias fácticas o jurídicas y, por ello, ya no sería posible dictar un acto con ese contenido. El principio de legalidad exige la eliminación de un acto que haya devenido antijurídico, mientras que el principio de seguridad jurídica no se opone a ello porque la estabilidad que con él se protege se refiere al momento en que el acto se dictó, pero no afecta a los cambios que se produzcan con posterioridad; cambios que no pudieron hacerse valer como motivos para impugnarlo ${ }^{65}$. También se ha destacado que los particulares podrían solicitar a la Administración competente que tomase las medidas adecuadas para tutelar sus derechos e intereses afectados por un acto que haya devenido ilegal y, si las circunstancias efectivamente han cambiado, ésta debería otorgar la tutela solicitada sin que el acto dictado en su momento fuera un obstáculo para ello66.

Concluyo. Creo que en el tema de la invalidez ha pasado ya el tiempo de la doctrina y es el momento del legislador, como demuestran los problemas que están planteando a diario las nulidad de los planes urbanísticos. Un legislador menos ensimismado y más atento a la mejor doctrina, no debería tener grandes dificultades para establecer un marco razonable y equilibrado sobre todas estas cuestiones y el resto que plantean los demás trabajos publicados en este mismo número.

\section{BIBLIOGRAFÍA CITADA}

ALCHOURRÓN, C. E. y BULYGIN, E. (2015): Sistemas normativos. Introducción a la metodología de las ciencias jurídicas, 2. ${ }^{a}$ ed., Buenos Aires-Bogota: Astrea.

ALEGRE ÁVILA J. M. (2012): "La invalidez sobrevenida de los actos jurídicos: inconstitucionalidad sobrevenida e invalidez sobrevenida de los actos administrativos", en Revista Andaluza de Administración Pública, núm. 83.

ATIENZA, M. y RUIZ MANERO, J. (2003), "Seis acotaciones para una teoría de la validez jurídica", en Doxa, núm. 26. DOI: $10.14198 /$ doxa2003.26.28.

BACA ONETO, V. S. (2006): La invalidez de los contratos, Cizur Menor: Thomson Civitas.

BAÑO LEÓN, J. M. a (2009): Derecho urbanístico común, Madrid: lustel.

BAÑO LEÓN, J. M. ${ }^{a}$ (2012): "La retroacción de actuaciones: ¿denegación de justicia o garantía del justiciable", en GARCÍA DE ENTERRÍA, E. y ALONSO GARCÍA, R.: Administración y Justicia. Un análisis jurisprudencial. Liber Amicorum Tomás-Ramón Fernández, Cizur Menor: Civitas Thomson Reuters.

BAÑO LEÓN, J. M. a (2017): “El plan urbanístico en ruina (un esbozo de reconstrucción)", en Práctica urbanística, núm. 144. BELADÍEZ ROJO, M. (1994a): Validez y eficacia de los actos administrativos, Barcelona: Marcial Pons.

62 En opinión de H. MAURER (2011: 267) «la invalidez sobrevenida de un acto administrativo ha de enjuiciarse según las reglas de la revocación».

63 Para las licencias urbanísticas por cambio de planeamiento, vid. J. M. ${ }^{a}$ BAÑO LEÓN (2009: 445-446).

64 M. REBOLLO PUIG y E. CARBONELL PORRAS (2018: 181). El art. 219.1 de la Ley General Tributaria dispone que la Administración tributaria podrá revocar sus actos en beneficio de los interesados «... cuando circunstancias sobrevenidas que afecten a una situación jurídica particular pongan de manifiesto la improcedencia del acto dictado».

${ }^{65} \mathrm{H}$. MAURER, (2011: 331), quien precisa que desde el punto de vista procesal, la revocación se solicitaría a través de una pretensión de condena dirigida a la obtención de un acto administrativo.

66 G. DOMÉNECH PASCUAL, (2005: 505). 
BELADÍEZ ROJO, M. (1994b): "La nulidad y la anulabilidad. Su alcance y significación", en Revista de Administración Pública, núm. 133.

BERDEJO LACRUZ, J. L., LUNA SERRANO, A., DELGADO ECHEVERRIA, J., RIVERO HERNÁNDEZ, F. (1987): Elementos de Derecho Civil, II, vol. II, 2. ${ }^{\text {a }}$ ed., Barcelona: Bosch.

BLANQUER CRIADO, D. (2014): "Disgresiones sobre la invalidez de los actos administrativos", en SORIANO GARCÍA, J. E. (dir.): Por el Derecho y la libertad. Libro homenaje al profesor Juan Alfonso Santamaría Pastor, volumen I, Madrid: lustel.

BOCANEGRA SIERRA, R. (1998): La anulación de oficio de los actos administrativos, Oviedo: Academia Asturiana de Jurisprudencia.

BOCANEGRA SIERRA, R. (2005): La teoría del acto administrativo, Madrid: lustel.

BOCANEGRA SIERRA, R. (2011): "La distinción entre la eficacia interna y la eficacia externa de los actos administrativos", en Revista Española de Derecho Administrativo, núm. 152.

BOCANEGRA SIERRA, R. (2012): Lecciones sobre el acto administrativo, Cizur Menor: Civitas Thomson Reuters.

BOQUERA OLIVER, J. M. ${ }^{a}$ (1993): Estudios sobre el acto administrativo, Madrid: Civitas.

CANO CAMPOS, T. (2004): La invalidez sobrevenida de los actos administrativos, Cizur Menor: Thomson Civitas.

CANO CAMPOS, T. (2011): "Privaciones patrimoniales y retractos forestales sin causa (un supuesto de invalidez sobrevenida de los actos administrativos)", en El Cronista del Estado Social y Democrático de Derecho, núm. 22.

CANO CAMPOS, T. (2012): "La imposibilidad de retrotraer actuaciones cuando se vulneran los derechos fundamentales en el procedimiento administrativo sancionador", en GARCÍA DE ENTERRÍA, E. y ALONSO GARCíA, R. (dirs.): Administración y Justicia. Un análisis jurisprudencial. Liber Amicorum Tomás-Ramón Fernández, Cizur Menor: Civitas Thomson Reuters.

CANO CAMPOS, T. (2016): "Validez e invalidez de los actos: teoría general”, en GAMERO CASADO, E. (dir.): Tratado de procedimiento administrativo común y régimen jurídico básico del sector público, Valencia: Tirant lo Blanch.

CANO CAMPOS, T. (2017): "Por qué se presume la validez de los actos administrativos" en MIGUEZ MACHO, L. y ALMEIDA CERREDA, M. (coord.), Los retos actuales del Derecho Administrativo en el Estado autonómico. Estudios en homenaje al profesor José Luís Carro Fernández-Valmayor, Andavira: Fundación Democracia y Gobierno Local.

CAPACCIOLI, E. (1956): La gestione di affari in diritto administrativo, Padova: Cedam.

CARRILLO DONAIRE, J. A. (2012): "Hacia la configuración de un derecho de reversión del ejercicio de tanteos y retractos forestales por pérdida sobrevenida de la causa. A propósito de la STS de 21 de marzo de 2011", en Revista Española de Derecho Administrativo, núm. 154.

CHINCHILLA MARÍN, C. (2011): "La invalidez sobrevenida de un retracto forestal: el transcurso del tiempo, la inactividad de la Administración y la actuación del interesado como factores invalidantes de un acto administrativo", en Justicia Administrativa, núm. 54.

COsculluela MONTANER, L. (2016): Manual de Derecho Administrativo, 27. ${ }^{a}$ ed., Cizur Menor: Civitas Thson Reuters.

DELGADO ECHEVERRÍA, J. y PARRA LUCÁN, M. A. (2003): De las nulidades de los contratos, www.unizar.es/ derecho/nulidad, Zaragoza.

DE OTTO Y PARDO, I. (2010): "La competencia del Tribunal Constitucional en relación con la Disposición Derogatoria de la Constitución", en Obras Completas, Madrid: CEPC.

DIEZ PICAZO, L. (2007): Fundamentos del Derecho civil patrimonial, I, 6. ${ }^{a}$ ed., Cizur Menor: Thomson Civitas.

DÍEZ SASTRE, S. (2012): La tutela de los licitadores en la adjudicación de los contratos públicos, Madrid: Marcial Pons.

DÍEZ SASTRE, S. (2017): "Los efectos de la invalidez en los procedimientos de adjudicación de contratos públicos", en LÓPEZ RAMÓN, F. y VILLAR ROJAS, F. (coord.), El alcance de la invalidez de la actuación administrativa. Actas del XII Congreso de la Asociación Española de Profesores de Derecho Administrativo, Madrid: INAP.

DíEZ-PICAZO JIMÉNEZ, L. M. ${ }^{\text {a }}$ (1990): La derogación de las leyes, Madrid: Civitas.

DOMÉNECH PASCUAL, G. (2002): La invalidez de los reglamentos, Valencia: Tirant lo Blanch.

DOMÉNECH PASCUAL, G. (2005): "Recensión al libro de T. Cano Campos, La invalidez sobrevenida de los actos administrativos, Civitas, Madrid, 2004", en Revista de Administración Pública, núm. 167.

ENTRENA CUESTA, R. (1999): Curso de Derecho Administrativo I, 13. ${ }^{a}$ ed., Madrid: Tecnos.

FERNÁNDEZ FARRERES, G. (2016): Sistema de Derecho Administrativo, Tomo I, 3. ${ }^{a}$ ed., Cizur Menor: Civitas Thomson-Reuters.

FERNÁNDEZ RODRÍGUEZ, T. R. (1969): "Los vicios de orden público y la teoría de las nulidades en el Derecho Administrativo", en Revista de Administración Pública, núm. 58.

FERNÁNDEZ RODRÍGUEZ, T. R. (1979): La nulidad de los actos administrativos, Caracas: Editorial Jurídica Venezolana.

FERRAJOLI, L. (2011): Principia luris. Teoría del derecho y de la democracia. 1. Teoría del derecho, Madrid: Trotta.

GAMERO CASADO, E. y FERNÁNDEZ RAMOS, S. (2016), Manual básico de Derecho Administrativo, $13 .{ }^{a}$ ed., Madrid, Tecnos. 
DA. Nueva Época - N. ${ }^{\circ}$, enero-diciembre 2018 - ISSN: 1989-8983 - DOI: 10.24965/da.v0i5.10605 - [Págs. 7-26]

Consideraciones generales sobre la invalidez en el Derecho Administrativo

Tomás Cano Campos (España)

GARCÍA DE ENTERRÍA, E. (1984): Los principios de la nueva Ley de Expropiación Forzosa. Potestad expropiatoria, garantía patrimonial, responsabilidad civil de la Administración, Madrid: Cívitas.

GARCÍA LUENGO, J. (2002): La nulidad de pleno derecho de los actos administrativos, Madrid: Civitas.

GARCÍA LUENGO, J. (2010): El reintegro de subvenciones, Cizur Menor: Civitas.

GARCÍA LUENGO, J. (2016): Las infracciones formales como causa de invalidez del acto administrativo. Un estudio sobre el artículo 48.2 de la Ley 39/2015, Madrid: Iustel.

GARRIDO FALLA, F. (1994): Tratado de Derecho Administrativo, tomo I, 12. ${ }^{a}$ ed., Madrid: Tecnos.

GARRORENA MORALES, A. (1999): "Artículo 164. Condiciones y efectos de las sentencias del Tribunal Constitucional”, ALZAGA VILLAAMIL, Ó. (dir.), en Comentarios a la Constitución Española de 1978, tomo XII, Madrid: Editoriales de Derecho Reunidas.

GASCÓN ABELLÁN, M. (1997): "Sentido y alcance de algunas distinciones sobre la invalidez de las leyes", en Doxa núm. 20. DOI: 10.14198/doxa1997.20.04.

GÓMEZ-FERRER RINCÓN, R. (2008): La imposibilidad de ejecución de sentencias en el proceso contenciosoadministrativo, Cizur Menor: Thomson Civitas.

GONZÁLEZ PÉREZ, J. (2011): Comentarios a la Ley de la Jurisdicción Contencioso-Administrativa (Ley 29/1998, de 13 de julio), 6. ${ }^{a}$ ed., Cizur Menor: Civitas Thomson Reuters.

GONZÁLEZ SANFIEL, A. M. (2017), “Límites a la declaración de nulidad del planeamiento", en LÓPEZ RAMÓN, F. y VILLAR ROJAS, F. (coord.), El alcance de la invalidez de la actuación administrativa. Actas del XII Congreso de la Asociación Española de Profesores de Derecho Administrativo, Madrid: INAP.

GUASTINI, R. (1999): Distinguiendo. Estudios de teoría y metateoría del Derecho (traducción de J. Ferrer i Beltrán), Barcelona: Gedisa.

GUASTINI, R. (2001): “Cinco observaciones sobre validez y derogación”, en Discusiones, núm. 2.

GUASTINI, R. (2010): Le fonti del Diritto. Fondamenti teorici, Milano: Giuffrè.

HUERGO LORA, A. (1999): "Irrecurribilidad de los actos confirmatorios y reproductorios y prescripción de derechos", en Revista Española de Derecho Administrativo, núm. 104.

HUERGO LORA, A. (2000): Las pretensiones de condena en el contencioso-administrativo, Cizur Menor: Aranzadi.

JIMÉNEZ CAMPO, J. (1997): "Qué hacer con la ley inconstitucional", en AA.VV, La sentencia sobre la constitucionalidad de la ley, Madrid: CEC (también en Rubio Llorente, F. y Jiménez Campo, J., Estudios sobre jurisdicción constitucional, Madrid: McGrawHill).

JORDANO FRAGA, J. (1996): Nulidad de actos administrativos y derechos fundamentales, Barcelona: Marcial Pons.

LAPORTA, F. J. (2007): El imperio de la ley. Una visión actual, Madrid: Trotta.

LETELIER WARTENBERG, R. (2011): Nulidad y restablecimiento en procesos contra normas, Cizur Menor: CivitasThomson Reuters.

LÓPEZ MENUDO, F. (1998): “Artículo 30", en Comentarios a la Ley de la Jurisdicción Contencioso-Administrativa de 1998. Edición especial del número 100 de la REDA, Madrid: Cívitas.

LÓPEZ RAMÓN, F. (2018): "La calificación de los vicios de los reglamentos", en Revista de Administración Pública, núm. 205. DOI: 10.18042/cepc/rap.205.01.

MATTARELLA, B. G. (2003): "Il provvedimento", en CASSESE, S. (dir.), Trattato di Diritto Amministrativo. Tomo I, $2 .{ }^{a}$ ed., Milano: Giuffrè.

MAURER, H. (2011): Derecho Administrativo. Parte general, (traducción coordinada por G. Doménech), Madrid: Marcial Pons.

MEDINA ALCOZ, L. (2005): La responsabilidad patrimonial por acto administrativo, Madrid: Thomson Civitas.

MENÉNDEZ GARCíA, P. (2001): "La revisión de oficio de actos y normas. Vía de lesividad y revocación de actos. Rectificación de errores. Experiencia tras la ley 4/1999", en Revista Gallega de Administración Publica, núm. 29.

MUÑOZ MACHADO, S. (2015): Tratado de Derecho Administrativo y Derecho público general, Tomo IV. El ordenamiento jurídico, Madrid: BOE.

MUÑOZ MACHADO, S. (2018): Tratado de Derecho Administrativo y Derecho público general, Tomo XII. Actos administrativos y sanciones administrativas, Madrid: BOE.

NIETO GARCÍA, A. (1994): "Estudio preliminar" al libro de Beladíez, M., Validez y eficacia de los actos administrativos, Madrid: Marcial Pons.

NINO, C. S. (2012): La validez del Derecho, Buenos Aires-Bogotá: Astrea.

PAREJO ALFONSO, L. (1981): "La Constitución y las leyes preconstitucionales. El problema de la derogación y la llamada inconstitucionalidad sobrevenida (A propósito de la jurisprudencia constitucional sobre el tema)", en $R A P$, núm. 94.

PASQUAU LIAÑO, M. (1997): Nulidad y anulabilidad del contrato, Madrid: Cívitas.

PASQUAU LIAÑO, M. (2007): "La acción de nulidad sí prescribe”, en DELGADO ECHEVERRÍA, J. (coord.), Las nulidades de los contratos: un sistema en evolución, Cizur Menor: Thomson Aranzadi.

PÉREZ LLEDÓ, J. A. (2015): "Normas constitutivas: reglas que confieren poderes y reglas puramente constitutivas. Las definiciones”, en GONZÁLEZ LAGIER, D. (coord.): Conceptos básicos del derecho, Madrid: Marcial Pons.

PRIETO SANCHÍS, L. (2005): Apuntes de Teoría del Derecho, Madrid: Trotta.

REBOLLO PUIG, M. (1995): El enriquecimiento injusto de la Administración pública, Madrid: Marcial Pons. 
REBOLLO PUIG, M. (1998): “Artículos 72 y 73", en Comentarios a la Ley de la Jurisdicción contencioso-administrativa de 1990. Edición Especial del número 100 de la Revista Española de Derecho Administrativo.

REBOLLO PUIG, M. (2005): "El reintegro de subvenciones", en FERNÁNDEZ FARRERES, G. (dir.), Comentario a la Ley General de Subvenciones, Cizur Menor: Thomson Civitas.

REBOLLO PUIG, M. (2005): "La presunción de validez", Revista Española de Derecho Administrativo, núm. 128.

REBOLLO PUIG, M. (2009): "La nulidad en Derecho Administrativo (consideración de su significado y régimen en el actual Derecho Administrativo español a propósito de la nulidad de los derechos fundamentales", en Justicia Administrativa, núm. 44.

REBOLLO PUIG, M. (2018): "La invalidez del acto administrativo", en REBOLLO PUIG, M. y VERA JURADO, D. J. (dirs.): Derecho Administrativo, Tomo II, $3 .^{a}$ ed., Madrid: Tecnos.

REBOLLO PUIG, M. y CARBONELL PORRAS, E. (2018): "La revisión de oficio", en REBOLLO PUIG, M. y VERA

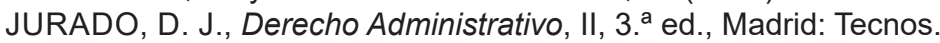

RODRÍGUEZ DE SANTIAGO, J. M. ${ }^{\text {a }}$ (2016): Metodología del Derecho Administrativo. Reglas de racionalidad para la adopción y el control de la decisión administrativa, Madrid: Marcial Pons.

RUBIO LLORENTE, F. (1990), "Prólogo" a Díez-Picazo Jiménez, L. M. a (1990), La derogación de las leyes, Madrid: Civitas.

SALA ARQUER, J. M. a (1974): La revocación de los actos administrativos en el Derecho español, Madrid: IEA.

SANTAMARÍA PASTOR, J. A. (1975): La nulidad de pleno derecho de los actos administrativos. Contribución a una teoría de la ineficacia en el Derecho público, 2. ${ }^{a}$ ed., Madrid: IEA.

SANTAMARÍA PASTOR, J. A. (2016): "El nuevo régimen de la revisión de oficio y de los recursos administrativos", en Revista Vasca de Administración Pública, núm. 105.

SANTAMARÍA PASTOR, J. A., LOZANO CUTANDA, B., QUINTANA CARRETERO, J. P., CASTILLO BADAL, R. (2014): 1700 dudas sobre la Ley de lo contencioso-administrativo, Madrid: La Ley.

TRAYTER JIMÉNEZ, J. M. (2015): Derecho Administrativo. Parte general, Barcelona: Atelier.

UTRILLA FERNÁNDEZ-BERMEJO, D. (2015): Expropiación forzosa y beneficiario privado. Una reconstrucción sistemática, Madrid: Marcial Pons.

VILLAR PALASÍ, J. L. y VILLAR EZCURRA, J. L. (1999): Principios de Derecho Administrativo II, Madrid: UCM. 